\title{
PATENT HOLDUP, THE ITC, AND THE PUBLIC INTEREST ${ }^{*}$
}

\author{
Colleen V. Chien† \& Mark A. Lemley††
}

\begin{abstract}
Patent-assertion entities, or "patent trolls," use the threat of injunction to hold up product-producing companies in patent suits. The Supreme Court's 2006 decision in eBay Inc. v. MercExchange, L.L.C. largely ended that practice, at least in federal courts. But it has had the unintended consequence of driving patent assertion entities to a different forum, the International Trade Commission (ITC), in hopes of obtaining injunctive relief no longer available in district courts. In this Article, we document that dramatic trend.

Because the ITC is an administrative agency, not a federal court, eBay's discretionary test for injunctive relief doesn't apply. And because the ITC can't award monetary damages, it has tended to grant injunctions as a matter of course. But as we suggest in this Article, the Commission has more power to adjust the remedies it grants than previously recognized. The ITC should use this flexibility to craft exclusion orders that limit the ability of a patentee to extract settlements that exceed the economic value of the patent, a practice called "holdup." For instance, delaying the implementation of exclusion orders and grandfathering in existing products could avoid holdup problems. The Commission could also use bond and penalty provisions to ensure that patentees receive compensation for ongoing infringement during these transition periods. If it uses its discretion wisely, the ITC can ensure that patentees are adequately rewarded without falling victim to the patent holdup problem that has beset district courts.
\end{abstract}

INTRODUCTION

I. THE RUSH TO THE ITC

II. EXCLUSION ORDERS AND THE PUBLIC INTEREST

* (C) 2012 Colleen V. Chien \& Mark A. Lemley.

$\dagger$ Assistant Professor, Santa Clara University School of Law.

$\dagger$ William H. Neukom Professor, Stanford Law School; partner, Durie Tangri LLP. An earlier version of this Article provided the basis for our editorial, Colleen V. Chien \& Mark A. Lemley, Op-Ed., Patents and the Public Interest, N.Y. TIMES (Dec. 13, 2011), http://www.nytimes.com/2011/12/13/opinion/patents-smartphones-and-the-public-interest.html. We thank Jonas Anderson, John Golden, Rose Hagan, Sapna Kumar, Stefani Schanberg, and participants at the 2012 UC Hastings IP Law Workshop and the Stanford-Samsung Conference on Patent Enforcement for helpful discussions; RPX Corporation and Lex Machina for sharing litigation data; and Gerald Wong, Lee-Ann Smith Freeman, Wesley Helmholz, Nichole Shanahan, and Wade Malone for research assistance. 
III. TAILORING, Bonding, AND PAUSING IN THE PUBLIC INTEREST ....125

A. Grandfathering and Tailoring Injunction Scope

B. Delay.....

C. Bonds and Penalties

D. Exercising Discretion Wisely

CONCLUSION

\section{INTRODUCTION}

In the wake of the Supreme Court's 2006 eBay Inc. v. MercExchange, L.L.C. decision, ${ }^{1}$ district courts rarely grant injunctions in patent infringement cases to patent-assertion entities (PAEs, also known as "patent trolls"). PAEs assert patents as a business model, traditionally using the threat of an injunction to reach a favorable settlement with the defendant. ${ }^{2}$ That threat often results in patent holdup. As Justice Anthony Kennedy articulated in his eBay concurrence, a holdup problem results when "an injunction ... can be employed as a bargaining tool to charge exorbitant fees." 3 By requiring federal courts to consider the equities of a particular case before granting an injunction, eBay solved much of the patent system's holdup problem.

But the Court's ruling didn't eliminate injunction-based holdup because another jurisdiction routinely grants injunctions in patent cases: the International Trade Commission (ITC). In the past five years, both PAEs and product-producing companies have flocked to this once-obscure trade agency in search of injunctions or the credible threat of injunctions. ${ }^{4}$ As the Commission itself explained: "[S]ince the U.S. Supreme Court's 2006 eBay decision, which has made it more difficult for patent-holders that do

1547 U.S. 388 (2006).

2 Colleen V. Chien, From Arms Race to Marketplace: The Complex Patent Ecosystem and Its Implications for the Patent System, 62 HASTINGS L.J. 297, 328 (2010) [hereinafter Chien, Arms Race to Marketplace] ("[PAEs are] entities ... focused on the enforcement, rather than the active development or commercialization of their patents."); see also FED. TRADE COMM'N, THE EVOlving IP MARKETPLACE: ALIGNing PATENT Notice AND REMEDies With COMPETITION 8 n.5 (2011), available at http://www.ftc.gov/os/2011/03/110307patentreport.pdf ("[T]he term 'patent assertion entity'.. refer[s] to firms whose business model primarily focuses on purchasing and asserting patents."). We use the term PAE at various points, rather than the more popular (and more all-encompassing) "nonpracticing entity" (NPE) because, as our data show, various types of NPEs do obtain injunctions after $e$ Bay while PAEs rarely do.

3 eBay, 547 U.S. at 396 (Kennedy, J., concurring).

4 See Sapna Kumar, The Other Patent Agency: Congressional Regulation of the ITC, 61 Fla. L. Rev. 529, 529, 532 (2009); Editorial, The Android Patent War, WAll ST. J., Dec. 5, 2011 A16, available

at http://online.wsj.com/article/SB10001424052970204826704577074523539966352.html (subscription required); see also The Evolving IP Marketplace: Hearing Before the Fed. Trade Comm'n, 127 (2009), available at http://ftc.gov/bc/workshops/ipmarketplace/apr17/transcript.pdf (statement of Laura G. Quatela, Chief Intellectual Property Officer and Vice President, Eastman Kodak Co.) ("[eBay has] driven a lot of litigation towards the ITC, and that trend is clear."). 
not themselves practice a patent to obtain injunctions in district courts, exclusion orders have increasingly been sought by non-practicing entities that hold U.S. patents." ${ }^{5}$ The result is that the ITC is busier with patent cases than it has ever been before. ${ }^{6}$

The double standard in patent law about when an injunction is available has drawn the scrutiny and, in some cases, the fury of the mainstream media, ${ }^{7}$ commentators, ${ }^{8}$ practitioners, ${ }^{9}$ Congress, ${ }^{10}$ and the

5 U.S. InT'L TRAde COMM'N, Budget Justification: FisCal Year 2012, at 21 (2011), available at http://www.usitc.gov/press_room/documents/budget_2012.pdf.

6 See, e.g., Jenna Greene, Record Number of ITC Cases Filed in First Half of 2011, THE BLT: THE BLOG OF Legal Times (June 30, 2011, 3:52 PM), http://legaltimes.typepad.com/blt/2011/06/record-number-of-itc-cases-filed-in-first-half-of2011.html. The ITC instituted fifty-six intellectual property investigations in the first nine months of 2011, as many as it did in all of 2010, and a record sixty-nine investigations throughout fiscal year 2011. Section 337 Statistical Information, U.S. INT'L TRADE COMM'N, http://www.usitc.gov/press_room/337_stats.htm (last visited Sept. 28, 2012).

7 See, e.g., Colleen V. Chien \& Mark A. Lemley, Op-Ed., Patents and the Public Interest, N.Y. TIMES (Dec. 13, 2011), http://www.nytimes.com/2011/12/13/opinion/patents-smartphonesand-the-public-interest.html? r=2; Editorial, Smoot-Hawley's Revenge, WALl ST. J., Aug. 23, 2006, at A10 (describing section 337 as "potentially crippling the U.S. wireless-phone industry"); Editorial, The Android Patent War, supra note 4 (calling an ITC patent case "a weapon of protectionist mass destruction against competitors" and section 337 an "absurdity . . . that could do great economic harm to one of the few U.S. industries that is growing rapidly").

8 See, e.g., K. William Watson, Cato Inst., Still a Protectionist Trade REMEDY: THE CASE FOR REPEALING SECTION 337, at 3 (2012), available at http://www.cato.org/pubs/pas/PA708.pdf (recommending that the ITC's section 337 patent authority be abolished); Thomas A. Broughan, III, Modernizing \& 337's Domestic Industry Requirement for the Global Economy, 19 FED. CIR. B.J. 41, 78-79 (2009) (noting and describing the divergence in federal court and ITC rules and law); Colleen V. Chien, Patently Protectionist? An Empirical Analysis of Patent Cases at the International Trade Commission, 50 WM. \& MARY L. REV. 63, 67-68 (2008) [hereinafter Chien, Patently Protectionist] (same); Taras M. Czebiniak, When Congress Gives Two Hats, Which Do You Wear? Choosing Between Domestic Industry Protection and IP Enforcement in \$ 337 Investigations, 26 BERKELEY TECH. L.J. 93, 93-94 (2011) (same); Robert W. Hahn \& Hal J. Singer, Assessing Bias in Patent Infringement Cases: A Review of International Trade Commission Decisions, 21 HARV. J.L. \& TECH. 457, 464 (2008) (same); Kumar, supra note 4, at 532-33 (same); see also Eric L. Lane, Keeping the LEDs on and the Electric Motors Running: Clean Tech in Court After eBay, 2010 DuKE L. \& TECH. REV. i, iii, $\mathrm{xxx}-\mathrm{xxxi}$ (noting that nonpracticing patentees have moved to the ITC to avoid $e B a y$ and warning that this may "adversely affect implemented clean technologies").

9 See, e.g., Edward H. Rice \& Marina N. Saito, After eBay: Can the ITC Offer Better Remedies than District Courts?, INTELl. PROP. LITIG., Winter 2008, at 13 passim, available at http://www.loeb.com/afterebaycantheitcofferbetterremediesthandistrictcourts/; James R. Klaiber \& Ethan Lee, Seeking Disapproval: Presidential Review of ITC Orders, LAw360 (Nov. 10, 2011, 12:51 PM), http://www.law360.com/articles/283970/seeking-disapproval-presidential-review-ofitc-orders (subscription required).

10 See The International Trade Commission and Patent Disputes: Hearing Before the Subcomm. on Intellectual Prop., Competition and the Internet of the H. Comm. on the Judiciary, 112th Cong. (2012) [hereinafter Hearing on the ITC and Patent Disputes] (statements of Colleen V. Chien, Santa Clara University Law School, Neal A. Rubin, Vice President of Litigation, Cisco Systems, Inc., and David B. Kelley, Intellectual Property Counsel, Ford Global Technologies LLC), available at http://judiciary.house.gov/hearings/Hearings\%202012/hear_07182012.html; Oversight of the Impact on Competition of Exclusion Orders to Enforce Standard-Essential Patents: Hearing Before the S. Comm. on the Judiciary, 112th Cong. (2012) (statement of Hon. 
Federal Trade Commission. ${ }^{11}$ In effect, the ITC's practices have undone many of the desirable consequences of $e B a y$.

The ITC issues exclusion orders ${ }^{12}$ that prevent the importation of a product. Exclusion orders can have a dramatic impact because, to comply with them, a company must pull its products from the market and redesign them. ${ }^{13}$ Many household devices, including computers, flat-screen televisions, GPS devices, and printers, have been the subjects of ITC section 337 investigations. ${ }^{14}$ In 2011, every major smartphone maker was embroiled in an ITC dispute..$^{15}$ As the impact of this trade agency has

Edith Ramirez, Comm'r, Federal Trade Commission), available at http://www.judiciary.senate.gov/hearings/hearing.cfm?id=45dca2a38e7309da19dce3a4cc06b817.

11 See FED. TRAdE COMM'N, supra note 2, at 239 ("[The] discrepancy [between the ITC and district court injunction standards] has generated some concern that the ITC may attract suits by patentees that are less likely to obtain injunctions in district court, potentially leading to holdup and ... resulting [in] consumer harm ....").

1219 U.S.C. $\S 1337(d)$ (2006). An ITC cease-and-desist order has a similar effect. Id. $\$ 1337$ (f).

13 See Kumar, supra note 4, at 538; see also Mark A. Lemley \& Carl Shapiro, Patent Holdup and Royalty Stacking, 85 TEX. L. REV. 1991, 1996 (2007) (discussing withdrawal from the market in the context of downstream firms).

14 See generally Certain Inkjet Ink Supplies and Components Thereof, Inv. No. 337-TA691, USITC Pub. 4290 (Nov. 2011) (Final) (printers); Certain Computer Products, Computer Components and Products Containing Same, Inv. No. 337-TA-628, USITC Pub. 4197 (Oct. 2010) (Final) (computers); Certain Flat Panel Digital Televisions and Components Thereof, USITC Inv. No. 337-TA-733, 75 Fed. Reg. 51,286 (Aug. 13, 2010) (Preliminary) (flat screens); Certain GPS Chips, Associated Software and Systems, and Products Containing Same, Inv. No. 337-TA-596, USITC Pub. 4133 (Mar. 2010) (Final) (GPS devices).

15 Certain Mobile Devices, Associated Software, and Components Thereof, Inv. No. 337-TA-744 (May 15, 2012) (Final) (Notice of a Commission Final Determination of Violation of Section 337; Issuance of a Limited Exclusion Order; Termination of Investigation; Respondent Motorola Mobility, Inc.); Certain Electronic Devices with Communication Capabilities, Components Thereof, and Related Software, Inv. No. 337-TA-808, 76 Fed. Reg. 60,870 (Sept. 30, 2011) (Preliminary) (Notice of Institution of Investigation; Institution of Investigation Pursuant to 19 U.S.C. 1337; Complainant HTC Corp. and Respondent Apple Inc.); Certain Wireless Devices with 3G Capabilities and Components Thereof, Inv. No. 337-TA-800, 76 Fed. Reg. 54,252, 54253 (Aug. 31, 2011) (Preliminary) (Notice of Institution of Investigation; Respondent Nokia Corp.); Certain Mobile Telephones and Modems, Inv. No. 337-TA-758, 2011 ITC LEXIS 1557 (Aug. 11, 2011) (Preliminary) (Order 17; Complainant Sony Corp. and Respondent LG Electronics, Inc.); Certain Electronic Devices, Including Wireless Communication Devices, Portable Music and Data Processing Devices, and Tablet Computers, Inv. No. 337-TA-794, 76 Fed. Reg. 45,860 (Aug. 1, 2011) (Preliminary) (Notice of Institution of Investigation; Institution of Investigation Pursuant to 19 U.S.C. 1337; Complainant Samsung Electronics Co. and Respondent Apple Inc.); Certain Mobile Telephones and Wireless Communication Devices Featuring Digital Cameras, and Components Thereof, at 2, Inv. No. 337-TA-703, 2011 ITC LEXIS 1112 (June 30, 2011) (Final) (Notice of Commission Determination to Affirm in Part and Reverse in Part a Determination of No Violation of Section 337; Remand of the Investigation for Further Proceedings; Respondents Apple Inc. and Research in Motion Ltd.). Major mobile handset and smartphone makers, based upon market share, include Apple, Samsung, Sony, LG, HTC, Motorola, Nokia, and RIM. See Raj Chowdary, Global Smartphone Sales for 2011 Pegged at 420 Million Units [Infographic], INFOGENRA (July 28, 2011), http://www.infogenra.com/global-smartphone-sales-for-2011-pegged-at-420-millionunits-infographic.html. 
grown, mainstream commentators have warned that the ITC "could do great economic harm to ... U.S. industries that [are] growing rapidly." 16 Calls for legislative reform of the ITC have also intensified ${ }^{17}$ based on the perception that the ITC's exclusion orders are "economically destructive and inflexible." 18 The difficulty is that the ITC can't award damages; it can only exclude products in what might seem to be an all-or-nothing affair. ${ }^{19}$

We believe, however, that the Commission has more flexibility in its choice of remedies than has previously been recognized. In this Article, we offer suggestions for how the ITC can use its statutory authority to minimize harm to the public interest when deciding both whether to grant an exclusion order and how to structure that order.

In the Parts that follow, we review the rules the ITC uses to decide whether to grant an injunction. ${ }^{20}$ While the U.S. Court of Appeals for the Federal Circuit has held that eBay's equitable test does not apply to the ITC,,$^{21}$ the agency must consider the effect of an injunction on the public before it orders one. ${ }^{22}$ To date, the ITC hasn't given these public interest factors many teeth. We think the ITC should pay more attention to the public interest, using prevailing economic theory and its precedents to assess the impact of patent injunctions on consumers and competitive conditions.

In a common patent infringement case, for example, the patent covers a small part of a larger product, and the defendant infringes it inadvertently.

16 Editorial, The Android Patent War, supra note 4.

17 See Michael A. Ladra, Latham \& Watkins, Domestic Disturbances: The Latest from the ITC on Establishing a Domestic Industry, Presentation at the 12th Annual Silicon Valley Advanced Patent Law Institute (Dec. 9, 2011) (describing fall 2011 efforts to lobby Congress to change the ITC); Bernard J. Cassidy, Follow the Money-Will the ITC Lose Its Patent Jurisdiction?, IPWATCHDOG (Feb. $\quad 27, \quad 2012, \quad 7: 05 \quad$ AM), http://www.ipwatchdog.com/2012/02/27/follow-the-money-will-the-itc-lose-its-patentjurisdiction/id=22470/ ("[The] 'ITC Working Group' . . . [is a lobby that] wants to block the International Trade Commission (ITC) from hearing patent infringement cases brought by 'non-practicing entities'-i.e., patent holders like universities, independent inventors, and others who license their patents for manufacturers to commercialize. And second, it wants to weaken the ITC's power to block the importation of infringing products into the U.S."). But see Chien \& Lemley, supra note 7 (arguing that legislative reform of the ITC is not necessary). Representative Devin Nunes has circulated a draft bill to eliminate the licensing prong of the domestic industry requirement, which would shut PAEs out of the ITC. Michael G. McManus \& Rodney R. Sweetland, ITC Continues to Set a High Bar for Licensing-Based Domestic Industries, MARTINDALE.COM (Sept. 3, 2012), http://www.martindale.com/administrative-law/article_DuaneMorris-LLP_1579880.htm.

18 Editorial, The Android Patent War, supra note 4.

19 See 19 U.S.C. § 1337(d), (f) (2006).

20 The ITC offers three forms of injunctive relief: a limited exclusion order, a general exclusion order, and a cease-and-desist order. Id. § 1337(d)-(f).

21 Spansion, Inc. v. ITC, 629 F.3d 1331, 1359 (Fed. Cir. 2010). For an argument that the eBay test should apply to the ITC, see FED. TRADE COMM'N, supra note 2, at 31-72.

$22 \quad$ See 19 U.S.C. $§ 1337$. 
If an interoperability standard covers the infringing feature, ${ }^{23}$ removing the feature may disable the product. ${ }^{24}$ Eliminating a big product from the market because of a small patent harms consumers, and blocking a large number of lawful components and features from the market along with the infringing one distorts competition. ${ }^{25}$

In another common situation, a patent holder sues a large number of companies, threatening to hobble an entire industry. An injunction would exclude many participants from the marketplace and dramatically reduce competition. ${ }^{26}$

In each of these scenarios, the harm to consumers and competition from an exclusion order is greater than the contribution made by the individual infringing component. As carmaker Ford put it: "By the time a manufacturer enters production, the company has spent great sums of money on design integration, tooling, and other investments to incorporate a particular technology. The technology itself may not be valuable-it may be trivial - but it is very expensive to change it after the investments have been made." 27

To address these harms, the ITC could decline to award exclusion orders at all. But this solution would leave the patentee without a remedy, at least in the ITC. Alternatively, the Commission could issue exclusion orders but structure them to ameliorate the harms to competition and consumers. In this Article, we discuss three methods of structuring injunctions to reduce harm: tailoring injunction scope, ${ }^{28}$ staying injunctions, and bonding.

These possibilities provide the ITC with previously unappreciated flexibility in ordering remedies. In a case in which the defendant can

23 On the prevalence of industry standards in many industries, see Mark A. Lemley, Intellectual Property Rights and Standard-Setting Organizations, 90 CALIF. L. REV. 1889, 189295 (2002) [hereinafter Lemley, Intellectual Property Rights].

24 For example, Innovatio IP Ventures has sued several companies including Cisco, Motorola, Accor North America, Caribou Coffee Co., Inc., Cosi, Inc., Dominick's Supermarkets, Inc., LQ Management LLC, Meijer, Inc., and Panera Bread Company on patents directed at the IEEE 802.11 standards, better known as "Wi-Fi." See Defendants' Motion to Stay This Matter Pending Resolution of Cisco Systems, Inc. and Motorola Solutions, Inc. v. Innovatio IP Ventures, LLC, No. 1:11-CV-00425 (D. Del.) at 1, 3, Innovatio IP Ventures, LLC v. ABP Corp., No. 1:11cv-01638 (N.D. Ill. Mar. 18, 2011), available at http://vmo-blog.com/files/10659899438/Innovatio_Ventures_(Customers_Motion_to_Stay).pdf. If a wireless router doesn't comply with this standard, it can't provide wireless services. See id. at 6-7.

25 See generally Lemley \& Shapiro, supra note 13, at 1992-93 (demonstrating how holdup costs affect manufacturers).

26 See S. REP. No. 93-1298, at 197 (1974).

27 Hearing on the ITC and Patent Disputes, supra note 10, at 2 (statement of David B. Kelley, Intellectual Property Counsel, Ford Global Technologies LLC).

28 The proper scope of patent injunctions has recently come under greater scrutiny. See, e.g., Tivo Inc. v. EchoStar Corp., 646 F.3d 869, 879, 889 (Fed. Cir. 2011) (en banc); John M. Golden, Injunctions as More (or Less) than "Off Switches": Patent-Infringement Injunctions' Scope, 90 TEX. L. REV. 1399, 1400-02 (2012) [hereinafter Golden, Injunctions]. 
design around the infringing component of a product, for example, awarding an injunction but delaying its start could deter infringement in a way that would minimize disruption to consumers and holdup to manufacturers. ${ }^{29}$ And delay can achieve these benefits without interfering with patentee incentives: In addition to bringing a case in the ITC, patentees can seek damages in federal court for infringing sales. If the patent were truly essential, the patentee could obtain an injunction after the stay expired. Alternatively, a change to the ITC's governing statute, 19 U.S.C. $\S 1337$, or the way the Commission applies it, would enable the ITC to extend the terms of the bond it normally sets during the presidential review period to compensate for the entire stay period. ${ }^{30}$

Some cases may warrant more significant limitations on exclusion orders. Suppose, for instance, that an infringing component is small but, because of the nature of the product, the potential impact of an exclusion order on downstream products, related products, and third parties is large. In such a case, the Commission could tailor the scope of the injunction to reduce harm to competition by grandfathering in existing products.

The ITC already has the ability to use the injunction levers we have identified in these situations. ${ }^{31}$ In this Article, we explain why the ITC has this power and develop the economic grounding for how the Commission could apply it. Alternatively, if the ITC won't use its existing public interest authority (or if the Federal Circuit won't let it), Congress could easily act to apply eBay to the ITC. But we don't think that sort of congressional action is necessary ${ }^{32}$ : the ITC has proven to be adaptive to the changing conditions of competition, and the agency is in a better position than the Federal Circuit or Congress to adapt its decision making to the particular facts before it. Indeed, Congress has even given the ITC the authority to take into account consumers and competition. The ITC, in short, already has the power to factor in the effect of an exclusion order on competition; now it must use that power.

A move away from the current practice of issuing automatic, immediate, and comprehensive exclusion orders does have a downside: it decreases the clarity about the remedy and the predictability that has long been associated with the ITC. But we think this loss of certainty is outweighed by the benefits to competition of tailoring remedies to the facts

29 See, e.g., Lemley \& Shapiro, supra note 13, at 2035-40 (showing that a stay in injunctive relief to allow design-arounds significantly reduces holdup risk).

30 See 19 U.S.C. $§ 1337(\mathrm{j})$ (2006) (describing the presidential review process). Effecting such a change might require tweaking the statutory language or delaying final entry of ITC orders pending the period of delay. See infra Part III.C.

31 Cf. infra Part III (describing the limited times in which the ITC has used these injunction-tailoring methods before).

32 And, indeed, one of us has relayed this opinion to Congress. See Hearing on the ITC and Patent Disputes, supra note 10 (statement of Colleen V. Chien, Santa Clara University School of Law). 
of the case. And the ITC can use early proceedings on issues of public interest and remedy ${ }^{33}$ to provide notice to litigants about the likelihood and form of an exclusion order if the patentee prevails.

In Part I of this Article, we examine how eBay has affected patent law and practice, both in the federal district courts and in the ITC. In particular, our empirical study shows a major shift in forum to the ITC, particularly by PAEs filing complaints against multiple defendants. In Part II, we review the public interest factors the ITC must consider before awarding an exclusion order and describe how the economic theory of holdup maps to these factors. In Part III, we discuss the ITC's options for tailoring injunctive relief.

\section{I}

\section{THE RUSH TO THE ITC}

The Supreme Court's 2006 decision in eBay $^{34}$ represented a sea change in patent litigation. Before 2006, a patentee who won its case was entitled to an injunction that prevented the defendant from selling its product. ${ }^{35}$ The result was a significant problem of patent holdup. ${ }^{36}$ Patentees who owned rights in very small pieces of complex, multicomponent products could threaten to shut down the entire product. ${ }^{37}$ As a result, even a very weak patent could command a high royalty in settlement from defendants afraid of gambling their entire product on a jury's decision. ${ }^{38}$

eBay changed this dynamic. Under eBay, district courts must consider four equitable factors before granting an injunction, including whether money damages are adequate and whether public and private interests, on balance, favor granting or denying the injunction. ${ }^{39}$ Justice Kennedy, concurring in eBay, emphasized that injunctions might be inappropriate when the plaintiff licenses the patent as a business model or when the patent covers only a small component of the product. ${ }^{40}$

Courts have considered these factors for centuries in deciding whether

\footnotetext{
33 Using a motion analogous to a summary judgment motion in district court, parties in the ITC can move for summary determination on any issue in a section 337 investigation. Summary Determinations, 19 C.F.R. $\S 210.18$ (2012).

34 eBay Inc. v. MercExchange, L.L.C., 547 U.S. 388 (2006).

35 See Lemley \& Shapiro, supra note 13, at 2008-09.

36 See id.

37 See id.

38 See id.

39 See eBay, 547 U.S. at 391.

40 See id. at 396-97 (Kennedy, J., concurring) ("When the patented invention is but a small component of the product the companies seek to produce and the threat of an injunction is employed simply for undue leverage in negotiations, legal damages may well be sufficient to compensate for the infringement and an injunction may not serve the public interest.").
} 
or not to award an injunction. ${ }^{41}$ The four-factor test reflects the Supreme Court's often-repeated belief that an injunction is an "extraordinary remedy." ${ }_{22}$ In the marketplace, a product injunction disrupts the free flow of goods and services, impacting not only the parties but also the public, who must abruptly adjust to life without the enjoined product or service. ${ }^{43}$ By its terms, eBay prescribes injunctive relief as a last-ditch option, justified only when money can't fix the harm and when the hardships and public interest, carefully considered, weigh in favor of an injunction. ${ }^{44}$

Commentators predicted that $e$ Bay would make injunctions harder to get. ${ }^{45}$ They were right. Based on our review of district court decisions since $e B a y,{ }^{46}$ courts grant about $75 \%$ of requests for injunctions, ${ }^{47}$ down from $95 \%$ pre-eBay. ${ }^{48}$ Another consequence of the decision is that courts now distinguish between different types of entities and their different types

41 See Douglas Laycock, The DeAth of THE IRREPARABle InJuRy Rule 19-23 (1991) (tracing the origins of the "irreparable injury rule" to the specialization in remedies by the courts of chancery and the courts of law in fourteenth-century Britain and the transmission of the rule to the courts of the colonies and United States in the seventeenth century). But see DougLAS LAYCOCK, MOdERn AMERICAN REMEdies: CASES AND MATERIALS 426-27 (3d ed. 2002) (criticizing the majority's characterization of the traditional four-factor test as the norm in remedies law).

42 See, e.g., Weinberger v. Romero-Barcelo, 456 U.S. 305, 312 (1982) (citing R.R. Comm'n v. Pullman Co., 312 U.S. 496, 500 (1941)); see also Rizzo v. Goode, 423 U.S. 362, 379 (1976) ("[T]he principles of equity . . militate heavily against the grant of an injunction except in the most extraordinary circumstances.").

43 See, e.g., Broadcom Corp. v. Qualcomm Inc., No. SACV 05-467 JVS (RNBx), 2007 U.S. Dist. LEXIS 97647, at *15, *20, *28 (C.D. Cal. Dec. 31, 2007) (citing the harm to the public that removing a "beneficial, cutting-edge service" from millions of customers would cause and tailoring the injunction to allow for an eighteen-month transition period); Paice LLC v. Toyota Motor Corp., No. 2:04-CV-211-DF, 2006 U.S. Dist. LEXIS 61600, at*16 (E.D. Tex. Aug. 16, 2006) (discussing the potential disruption of an injunction against Toyota's hybrid cars to car dealers, parts suppliers, and related business entities), aff'd in part, vacated in part, and remanded, 504 F.3d 1293 (Fed. Cir. 2007).

44 See eBay, 547 U.S. at 391-92. For an argument that courts should consider effects on innovation directly when evaluating injunctions, see generally Sarah R. Wasserman Rajec, Tailoring Remedies to Spur Innovation, 61 AM. U. L. REV. 733 (2012).

45 See, e.g., Steve Seidenberg, Troll Control, A.B.A. J., Sept. 2006, at 51, 52.

46 Using data from Patstats.org, we analyzed 144 decisions from July 26, 2006 to August 5, 2011. In a few instances that we checked, the injunction was later vacated due to a change in the court's liability determination. However, because the later determination did not challenge the reasoning of the court in these instances, we kept the cases and the decisions on injunction in our database. An updated version of the database, through December 4, 2011, includes over 200 decisions. U.S. Patent Litigation Statistics, PATSTATS.ORG, http://patstats.org/Patstats2.html (last visited Sept. 28, 2012) (click on "Post-eBay Permanent Injunction Rulings in Patent Cases to 7-30-12").

47 Accord Fed. TRAde Comm'N, supra note 2, at 217 (reporting an injunction rate of $72 \%$ to $77 \%)$.

48 See Kristy Downing \& Gary Frischling, Injunctive Relief After eBay v. MercExchange, Presentation to the AIPLA 2007 Annual Patent Law Committee 12 (Oct. 19, 2007), available at http://www.justintellectuals.com/publications/InjunctiveReliefAfterEbay.ppt (describing the preeBay injunction rate at about $95 \%$ ). 
of behavior. Among different types of nonpracticing entities (NPEs), ${ }^{49}$ individuals and universities have enjoyed higher-than-average injunction-grant rates, but courts have denied injunctions to PAEs about three-quarters of the time. When the injunction was contested, the PAE denial rate was over $90 \%$, as Figure 1 shows..$^{50}$

\section{INSERT FIGURE 1 HERE}

These results may seem surprising, particularly the finding that certain NPEs have been more successful than practicing companies at obtaining injunctions. Based on our analysis of post-eBay district court decisions, however, we found that courts have reached remarkably consistent results across a range of fact patterns. For example, courts deny practicing companies an injunction when those companies aren't practicing the particular patent they've asserted. ${ }^{51}$ Courts also deny injunctions when a practicing company can't show irreparable harm because it's part of a multiple-competitor market, precluding the court from concluding that the defendant's gains have come at the plaintiff's expense. ${ }^{52}$

Conversely, universities, which do not practice their own patents, have been able to win injunctions by suing on behalf of their exclusive licensees who are in fact practicing the patent. ${ }^{53}$ Of all groups, PAEs are least likely to obtain an injunction; they tend to succeed in their requests only when the defendant fails to object. ${ }^{54}$ In the single post-eBay case we found in which

49 This term is broader than PAE because it includes universities and individuals.

50 We assumed that any denied injunction request was a "contested" injunction request.

51 See, e.g., Ricoh Co. v. Quanta Computer, Inc., No. 06-cv-462-bbc, 2010 U.S. Dist. LEXIS 38220, at *3-4 (W.D. Wis. Apr. 19, 2010), aff'd in part and vacated in part, No. 20071567, 2011 U.S. App. LEXIS 6660 (Fed. Cir. Mar. 4 2011). This case was described in the press under the headline "Ricoh Gets the Troll Treatment." Jan Wolfe, Patent Litigation Weekly: At Injunction Time, Ricoh Gets the Troll Treatment, THE PRIOR ART (Apr. 28, 2010), http://thepriorart.typepad.com/the_prior_art/2010/04/ricoh-v-quanta.html.

52 See, e.g., LG Elecs. U.S.A. v. Whirlpool Corp., 798 F. Supp. 2d 541, $562-63$ (D. Del. 2011); Robert Bosch, LLC v. Pylon Mfg. Corp., 748 F. Supp. 2d 383, 408 (D. Del. 2010), rev'd, 659 F.3d 1142 (Fed. Cir. 2011); Advanced Cardiovascular Sys., Inc. v. Medtronic Vascular, Inc., 579 F. Supp. 2d 554, 559-60 (D. Del. 2008).

53 See, e.g., Emory Univ. v. Nova Biogenetics, Inc., No. 1:06-CV-0141-TWT, 2008 U.S. Dist. LEXIS 57642, at *3-4, *12-13 (N.D. Ga. July 24, 2008); Johns Hopkins Univ. v. Datascope Corp., 513 F. Supp. 2d 578, 581 (D. Md. 2007), rev'd and remanded, No. 2007-1530, 2008 U.S. App. LEXIS 20740 (Fed. Cir. Oct. 2, 2008).

For a discussion of universities as NPEs, see generally Mark A. Lemley, Are Universities Patent Trolls?, 18 FORDHAM INTELL. PROP. MEDIA \& ENT. L.J. 611, 629-30 (2008) (arguing that they aren't).

54 PAEs have obtained five injunctions since $e$ Bay. Systemation, Inc. v. Prod. Prods., Inc., No. 1:11-cv-487-LPS, slip op. at 1-2 (D. Del. June 27, 2011) (entering an injunction because two of the parties settled); Irrevocable Trust of Antonious v. Merchs. of Golf, Inc., No. CV 10-02634 ODW (CWx), 2011 U.S. Dist. LEXIS 3332, at *1-2 (C.D. Cal. Jan. 5, 2011) (setting aside a default judgment and an injunction previously entered because the defendant failed to respond); PB\&J Software, LLC v. Code 42 Software, Inc., No. 09-cv-00206 DWF/JSM (D. Minn. Sept. 3, 2010), (entering a final judgment for permanent injunctive relief against defendant Cucku, Inc., who stipulated to this relief); Joyal Prods., Inc. v. Johnson Elec. N. Am., Inc., No. 04-5172 (JAP), 2009 U.S. Dist. LEXIS 15531, at*30-31, *33 (D.N.J.) (granting an injunction where the plaintiff 
a no-longer-practicing company sued and succeeded in receiving a contested injunction, the court cited its belief that the company would sell the patent to a manufacturer. ${ }^{55}$

When applying eBay, courts have focused on the irreparable injury and adequate remedy at law factors. ${ }^{56}$ Competitive considerations predominate: courts grant injunctions when the defendant's infringement credibly threatens the market share, ${ }^{57}$ reputation, ${ }^{58}$ or business model ${ }^{59}$ of the plaintiff and deny injunctions when these harms are absent. ${ }^{60}$ Predicted

was not an ongoing business and looked to sell its patent because failure to grant an injunction would severely affect the sale value of the patent), aff' $d$, No. 2009-1095, 2009 U.S. App. LEXIS 23315 (Fed. Cir. Oct. 22, 2009); Acticon Techs. v. Heisei Elecs. Co., No. 06-CV-4316 (KMK), 2008 U.S. Dist. LEXIS 8978, at *2-3 (S.D.N.Y. Feb. 5, 2008) (adopting the magistrate judge's findings because the defendant failed to object to the magistrate judge's report), adopting, No. 06 Civ. 4316(CM)(MDF), 2007 U.S. Dist. LEXIS 100081, at*10-12 (S.D.N.Y. Aug. 1, 2007). But see Voda v. Cordis Corp., No. CIV-03-1512-L, 2006 U.S. Dist. LEXIS 63623, at *18-19, *21 (W.D. Okla. Sept. 5, 2006) (denying an injunction because harm to the right to exclude was not enough to justify granting one), aff'd in relevant part and rev'd in relevant part, 536 F.3d 1311, 1315 (Fed. Cir. 2008)

55 Joyal Prods., 2009 U.S. Dist. LEXIS 15531, at *30-31 (holding that the ailing plaintiff's patents would be worth less in the marketplace if the company was unable to or incapable of excluding others, and "the most likely purchaser of the patent would be a manufacturer"). But see Voda, 2006 U.S. Dist. LEXIS 63623, at *18-19, *21 (finding that harm to the right to exclude is not enough to justify an injunction).

56 It is hard to come up with circumstances that would distinguish irreparable injury from the absence of an adequate remedy at law.

57 A number of courts have cited market-share-related reasons in deciding to grant injunctions. See i4i Ltd. P'ship v. Microsoft Corp., 670 F. Supp. 2d 568, 599-601 (E.D. Tex.) (citing injury to market share and brand), aff'd in relevant part, 589 F.3d 1246 (Fed. Cir. 2009); Findings of Fact, Conclusions of Law, and Order for Injunctive Relief at 9, Global Traffic Techs. LLC v. Tomar Elecs., Inc., No. 05-756 MJD/AJB (D. Minn. Jan. 21, 2009) (market share, customer relationships); Emory, 2008 U.S. Dist. LEXIS 57642, at *12 (citing competition in a two-competitor market); Johns Hopkins, 513 F. Supp. 2d at 586 (same); Broadcom Corp. v. Qualcomm Inc., No. SACV 05-467 JVS (RNBx), 2007 U.S. Dist. LEXIS 97647, at*16 (C.D. Cal. Dec. 31, 2007) (citing market-share injury based on "the 'design-win' nature of the market"); Wald v. Mudhopper Oilfield Servs., Inc., No. CIV-04-1693-C, 2006 U.S. Dist. LEXIS 51669, at *16 (W.D. Okla. July 27, 2006) (citing injury to market share and damage to reputation); see also Advanced Cardiovascular, 579 F. Supp. 2d at 558 (noting that injunctions are usually granted in two-competitor-market scenarios).

58 See, e.g., Emory, 2008 U.S. Dist. LEXIS 57642, at *12-13 (citing harm to reputation and goodwill); Commonwealth Scientific \& Indus. Research Org. v. Buffalo Tech. Inc., 492 F. Supp. $2 \mathrm{~d} 600,604$ (E.D. Tex. 2007) (citing harm to reputation), vacated and remanded on other grounds, 542 F.3d 1363 (Fed. Cir. 2008); Johns Hopkins, 513 F. Supp. 2d at 586 (same).

59 See, e.g., ReedHycalog UK, Ltd. v. Diamond Innovations Inc., No. 6:08-CV-325, 2010 U.S. Dist. LEXIS 83011, at *35-36 (E.D. Tex. Aug. 12, 2010) (granting an injunction where the court found disruption to the plaintiff's business, licensing, and pricing strategy); Judkins v. HT Window Fashions Corp., 704 F. Supp. 2d 470, 477 (W.D. Pa. 2010) (granting an injunction where an exclusive licensor would experience harm to business relationships); Joyal Prods., 2009 U.S. Dist. LEXIS 15531, at $* 30-31$ (finding that the denial of an injunction would decimate the value of the patent in a planned asset sale).

60 See, e.g., LG Elecs. U.S.A., Inc. v. Whirlpool Corp., 798 F. Supp. 2d 541, 563 (D. Del.) (citing the presence of a multiple-competitor market), rev'd and remanded, No. 2011-1096, 2011 U.S. App. LEXIS 20700 (Fed. Cir. Oct. 13, 2011); Enpat, Inc. v. Budnic, 773 F. Supp. 2d 1311, 1317 (M.D. Fla.), injunction granted, No. 6:11-cv-86-PCF-KRS, 2011 U.S. Dist. LEXIS 37440 
loss of market share, reputation, and goodwill are difficult to quantify and restore, making money damages inadequate in cases in which these harms occur. ${ }^{61}$ Entities that don't sell products typically don't experience these types of injuries. ${ }^{62}$

The relationship between the patented invention and the enjoined product also matters to courts. Following Justice Kennedy's suggestion, ${ }^{63}$ when the patented invention covers a small component of the defendant's product, courts have been less inclined to award an injunction. ${ }^{64}$ Courts

(Fed. Cir. Mar. 29, 2011); Robert Bosch, LLC v. Pylon Mfg. Corp., 748 F. Supp. 2d 383, 408 (D. Del. 2010) (citing the presence of a multiple-competitor market), rev'd, 659 F.3d 1142 (Fed. Cir. 2011); Ricoh Co. v. Quanta Computer, Inc., No. 06-cv-462-bbc, 2010 U.S. Dist. LEXIS 38220, at *3-4 (W.D. Wis. Apr. 19, 2010) (finding that plaintiff was not in competition with defendant because plaintiff did not practice invention), aff'd in part and vacated in part, No. 2007-1567, 2011 U.S. App. LEXIS 6660 (Fed. Cir. Mar. 4 2011); Hynix Semiconductor Inc. v. Rambus Inc., 609 F. Supp. 2d 951, 984-85 (N.D. Cal. 2009) (finding no harm to reputation but harm to defendant's business); Telcordia Techs., Inc. v. Cisco Sys., 592 F. Supp. 2d 727, 747 (D. Del. 2009) (finding no evidence of "lost sales, licensing, or research and development opportunities"); Creative Internet Adver. Corp. v. Yahoo!, 674 F. Supp. 2d 847, 852 (E.D. Tex. 2009); Advanced Cardiovascular, 579 F. Supp. 2d at 559 (citing the presence of a multiple-competitor market); Am. Calcar, Inc. v. Am. Honda Motor, No. 06cv2433 DMS (CAB), 2008 U.S. Dist. LEXIS 106476, at *2-3 (S.D. Cal. Nov. 18, 2008) (finding insufficient evidence of lost opportunities and harm to reputation); Orion IP, LLC v. Mercedes-Benz USA, LLC, No. 6:05 CV 322, 2008 U.S. Dist. LEXIS 108683, at*12 (E.D. Tex. Mar. 28, 2008); Nichia Corp. v. Seoul Semiconductor, Ltd., No. 06-0162 MMC, 2008 U.S. Dist. LEXIS 12183, at *5 (N.D. Cal. Feb. 7, 2008) (finding no loss of market share, reputation or brand); Sundance, Inc. v. Demonte Fabricating Ltd., No. 02-73543, 2007 U.S. Dist. LEXIS 158, at *8 (E.D. Mich. Jan. 4, 2007) (citing the presence of a multiple-competitor market); Paice LLC v. Toyota Motor Corp., No. 2:04-CV-211-DF, 2006 U.S. Dist. LEXIS 61600, at *13-14 (E.D. Tex. Aug. 16, 2006) (finding the plaintiff unable to prove damage to market share or brand name and finding no evidence that money damages were inadequate to compensate licensing company's loss), aff'd in part, vacated in part, and remanded, 504 F.3d 1293 (Fed. Cir. 2007); WhitServe LLC v. Computer Packages, Inc., No. 3:06CV01935 (AVC) (D. Conn. Mar. 30, 2011) (denying an injunction because there was no evidence of lost market share, customers, or goodwill).

61 Emory, 2008 U.S. Dist. LEXIS 57642, at *13.

62 NPEs sometimes assert injury to their reputation resulting from the fact that the defendant used a product that turned out to be covered by the patent claims. See Commonwealth Scientific \& Indus. Research Org., 492 F. Supp. 2d at 604. This theory strikes us as wildly implausible. To the extent consumers are even aware of the patent and the fact that the defendant infringes it, it's hard to see how awareness of that fact will injure the NPE's reputation. If anything, the widespread use of the patentee's technology should enhance its reputation.

63 eBay Inc. v. MercExchange, L.L.C., 547 U.S. 388, 396-97 (2006) (Kennedy, J., concurring).

64 See Ricoh, 2010 U.S. Dist. LEXIS 38220, at *6 (noting that the component at issue was a small part of the overall product); Sundance, 2007 U.S. Dist. LEXIS 158, at *7-8 (noting that the patented technology was but one feature of the defendant's product); z4 Techs., Inc. v. Microsoft Corp., 434 F. Supp. 2d 437, 441 (E.D. Tex. 2006) (stating that in a small component scenario, damages are sufficient); see also Broadcom Corp. v. Qualcomm Inc., No. SACV 05-467 JVS (RNBx), 2007 U.S. Dist. LEXIS 97647, at*19-21 (C.D. Cal. Dec. 31, 2007) (tailoring the injunction to ameliorate the impact on consumers by providing time for design-around when the scope of the infringed patent is limited); Steve Malin \& Ari Rafilson, Sidley Austin LLP, Empirical Analysis of Permanent Injunction Decisions Following eBay 29 (Feb. 12, 2009), available at http://www.ftc.gov/bc/workshops/ipmarketplace/feb11/docs/smalin.pdf (reporting a district court injunction rate of $0 \%$ when the invention was a "trivial component" of a product, as 
have also taken into account the impact of an injunction on consumers under the auspices of the public interest prong of the four-factor test. ${ }^{65}$

Hundreds of district courts throughout the country have thus engaged in the same process of considering whether an injunction is justified in patent infringement cases. Yet one decision maker has been exempt from doing so. The ITC, an administrative agency rather than Article III court, has declined to follow eBay-a practice that the Federal Circuit has approved. ${ }^{66}$ This apparent anomaly has a simple explanation: although the ITC applies patent law $^{67}$ to decide whether an unlawful importation has occurred, ${ }^{68}$ the Commission follows its own procedures and prescribes its own remedies. As the Federal Circuit explained in Spansion, Inc. $v$. International Trade Commission, "[there are] different statutory underpinnings for ... Section 337 actions [in the ITC] and... district courts in suits for patent infringement." ${ }^{69}$ As a result, the ITC neither hears counterclaims nor recognizes certain defenses to infringement, ${ }^{70}$ and it can't award damages. ${ }^{71}$ Congress foreclosed these district court options to speed ITC proceedings, ${ }^{72}$ reflecting its original intent for the ITC to offer a special solution to the problem of foreign infringement. ${ }^{73}$ Now that most technology products are manufactured overseas ${ }^{74}$ and Congress has relaxed

compared to $75 \%$ grant rate when the infringing feature was not a trivial component).

65 See, e.g., Amgen, Inc. v. Hoffman-La Roche Ltd., 581 F. Supp. 2d 160, 213 (D. Mass.) (considering patient health, Medicare savings, and the public's interest in a robust patent system in deciding whether to grant an injunction), aff'd per curiam, No. 2008-1300, 2008 U.S. App. LEXIS 21702 (Fed. Cir. Oct. 10, 2008).

66 Spansion, Inc. v. ITC, 629 F.3d 1331, 1359 (Fed. Cir. 2010).

67 In addition to patent law, the ITC also applies other forms of intellectual property law. See TianRui Grp. Co. v. ITC, 661 F.3d 1322, 1326-27 (Fed. Cir. 2011) (confirming that section 337 applies to imported goods produced through the exploitation of trade secrets). The majority of section 337 cases, however, are patent cases. See Chien, Patently Protectionist, supra note 8, at $70 \&$ n.123 (stating that patent cases make up $85 \%$ of the ITC's section 337 docket and explaining why copyright and trademark cases are less likely to be brought in the ITC). The Commission has heard a handful of antitrust cases, and commentators have speculated that the ITC could also decide child labor and other violations. See, e.g., A LAWYER's GUIDE TO SECTION 337 InVESTIGATIONS BEFORE THE U.S. INTERNATIONAL TRADE COMMISSION 226-27 (Tom M. Schaumberg ed. 2010). One pending bill would give the ITC the authority to oversee the issuance of cease-and-desist orders against "rogue websites" for copyright infringement. Online Protection and Enforcement of Digital Trade Act, H.R. 3782, 112th Cong. (2012).

6819 U.S.C $\$ 1337(\mathrm{a})(1)(\mathrm{B})(2006)$.

69629 F.3d at 1359.

70 See Kinik Co. v. ITC, 362 F.3d 1359, 1361-63 (Fed. Cir. 2004) (holding that 35 U.S.C. $\S 271(\mathrm{~g})(2)$ does not apply in the ITC); Colleen V. Chien, Protecting Domestic Industries at the ITC, 28 SANTA ClaRa COMPUTER \& High TECH. L.J. 169, 171 (2011) ("In an ITC proceeding, there are no juries, no counterclaims, few stays for reexamination, and no damages." (footnotes omitted)) [Colleen V. Chien, Protecting Domestic Industries].

$71 \quad$ See 19 U.S.C. $\$ 1337$.

72 See Czebiniak, supra note 8, at 93-94, 105-06.

73 See id. at 95.

74 See, e.g., Certain Personal Data and Mobile Communications Devices and Related Software, Inv. No. 337-TA-710, USITC Pub. 4331, at 77 (July 15, 2011) (Final) (commission 
the domestic industry requirement, ${ }^{75}$ nearly every patentee can bring an ITC complaint, and nearly every accused infringer is a potential ITC defendant, converting the ITC into a mainstream venue in which to file patent grievances. ${ }^{76}$

The history and structure of 19 U.S.C. $§ 1337$ mean that it is out of sync with the rest of the patent system in certain ways. Legislative and judicial improvements to patent law procedures and remedies simply don't apply in the ITC. When Congress recently enacted a rule limiting the naming of multiple defendants in a patent infringement lawsuit, ${ }^{77}$ for example, the reform did not extend to the ITC. ${ }^{78}$ While the number of defendants per case declined in the district court immediately following passage of the law, it has remained steady in the ITC, as Figure 2 shows.

\section{INSERT FIGURE 2 HERE}

$e$ Bay has created the most pointed rift between district courts and the ITC. While the overall injunction rate in district courts has declined to $75 \%$ since eBay, prevailing patentees have continued to be able get injunctive relief relief at the ITC. ${ }^{79}$ (Figure 3) The difference in grant rates is even more dramatic for PAEs: they are unlikely to obtain an injunction from a district court ${ }^{80}$ but, based on the ITC's track record, are virtually guaranteed one in the ITC should they prevail. ${ }^{81}$ This discrepancy is due in part to the fact that injunctions are not only the preferred remedy at the ITC, they are the only remedy. ${ }^{82}$ As an agency whose administrative law

opinion) ("[T]o HTC's knowledge no smartphones . . . are produced in the United States; rather they are all manufactured overseas and imported in the United States." (first alteration in original) (quoting The HTC Respondents' Opening Brief on Commission Review at 161, Certain Personal Data and Mobile Communications Devices and Related Software, Inv. No. 337-TA-710 (2011) (USITC Pub. 4331))).

75 See InterDigital Commc'ns, LLC v. ITC, No. 2010-1093, 2012 WL 3104597, at *10-11 (Fed. Cir. Aug. 1, 2012) (finding that the relaxed domestic industry requirement can be satisfied by U.S. patentees licensing other imported products); John Mezzalingua Assocs. v. ITC, 660 F.3d 1322, 1327-28 (Fed. Cir. 2011) (discussing the statutory change that permitted PAEs to claim "domestic industry" status at the ITC and interpreting the new statute); Czebiniak, supra note 8, at 110 .

76 See Czebiniak, supra note 8, at 107-08. Figure 4, infra, reports the growth in the portion of ITC cases involving NPEs.

77 See Leahy-Smith America Invents Act, Pub. L. No. 112-29, § 19(d), 125 Stat. 284, 332 33 (2011) (codified as amended at 35 U.S.C. § 299 (Supp. V 2011)) (limiting joinder of defendants to cases relating to the same transactions, occurrences, or accused products).

78 See Chien, Protecting Domestic Industries, supra note 70, at 175.

79 See infra Figure 3.

80 See supra Figure 1.

81 See infra Figure 3. Although, as would be expected in a business model that uses the threat of an injunction, rather than an actual injunction, to get royalties, few NPEs have actually received an exclusion order. See U.S. INT'L TRADE COMM'N, FACTS AND TRENDS REGARDING USITC SECTION 337 INVESTIGATIONS $3, \quad$ available at http://www.usitc.gov/press_room/documents/featured_news/337facts.pdf (describing the cases where an NPE has been able to get an exclusion order) [hereinafter FACTS AND TRENDS].

82 See Spansion, Inc. v. ITC, 629 F.3d 1331, 1358 (Fed. Cir. 2010) (citing the statute's 
judges conduct investigations without juries, the ITC is not statutorily authorized to grant money damages. ${ }^{83}$

INSERT FIGURE 3 HERE

Litigants are aware of this limitation and view the ITC as being "a more advantageous forum for patent holders with what is viewed to be a less stringent standard for obtaining injunctive relief." ${ }^{84}$ NPEs are flocking to the ITC. ${ }^{85}$ In the years following $e$ Bay, the number of ITC investigations brought by NPEs has grown from two in 2006 to sixteen in 2011, and the number of total respondents named in NPE cases has grown from eight to 235 within the same time period. ${ }^{86}$ Growth in NPE-initiated ITC cases has outpaced that in ITC cases in general during this period, with the NPE share of all ITC cases growing from $7 \%$ to $25 \%{ }^{87}$ and the number of respondents from NPE-initiated ITC cases growing to over $50 \%$ of all ITC respondents, as Figure 4 shows. Based on a separate analysis of patents asserted over an eighteen-month period, we find that PAE complainants are more often than not using patents that they purchased, not technologies they invented. 88

legislative history for the proposition that "an injunction is the only available remedy for violations of Section 337").

83 See infra note 146 and accompanying text.

84 Albert B. Chen \& Matthew F. Abbott, Protecting Green Patents: District Court vs. ITC, LAw360 (Jan. 5, 2012, 12:46 PM), http://www.law360.com/articles/295637/protecting-greenpatents-district-court-vs-itc (subscription required).

85 See infra Figure 4; see also Robert D. Fram \& Ashley Miller, The Rise of Non-Practicing Entity Litigation at the ITC: The State of the Law and Litigation Strategy 10 (Oct. 22, 2010) (unpublished manuscript) (on file with authors) (finding an increase in the number of ITC complaints brought by companies relying on their licensing activities in accordance with 19 U.S.C. $\S 1337$ (a)(3)(c) to show standing from $13 \%$ from 2000 to 2006 to $27 \%$ from 2007 to August 2010).

86 We relied on a proprietary database of ITC cases maintained by RPX Corporation (RPX ITC Database) that includes NPE coding. To verify its reliability, we independently coded ninety-one investigations from January 2011 to June 2012, resulting in a 2\% disagreement rate. RPX includes in its definition of "NPE" universities and individuals as well as PAEs.

87 Using the RPX ITC Database, we determined that NPEs brought two out of twenty-seven ITC patent cases in 2006 and sixteen out of sixty-three ITC patent cases in 2011. The ITC's official statistics divide NPEs into Category 1 and Category 2 and show lower but still substantial growth in NPE cases, from around one out of fourteen (7\%) in the second half of 2006 to thirteen out of fifty-five (19\%) in 2011. See FACTS AND TRENDS, supra note 81, at 2. The growth in ITC cases is somewhat surprising in light of some commentators' concern that the ITC's decision in Kyocera Wireless Corp. v. International Trade Commission would result in a noticeable decline in ITC filings. 545 F.3d 1340 (Fed. Cir. 2008); see Christopher A. Cotropia, Strength of the International Trade Commission as a Patent Venue, 20 TEX. InTELl. Prop. L.J. 1, 3 (2011). This concern hasn't materialized. See Cotropia, supra, at 4.

88 Available assignment records at the U.S. Patent and Trademark Office indicate that at least fifteen of the twenty-three PAE investigations initiated between January 2011 and June 2012 were brought based on patents reassigned from their original owner, in some cases many times. For example, based on our analysis, patent 5,862,511 was reassigned seven times before being asserted by Beacon $\mathrm{GmbH}$ of Switzerland in the ITC investigation Certain Automotive GPS Navigation Systems, Components Thereof, and Products Containing Same, Inv. No. 337-TA-814, 76 Fed. Reg. 72,442 (Nov. 23, 2011) (Preliminary) (Notice of Institution of Investigation). 


\section{INSERT FIGURE 4 HERE}

This divergence in remedies undoes the progress eBay represents. ${ }^{89}$ Parties who win in district court but would not receive an injunction under $e$ Bay can circumvent this result by refiling their cases in the ITC $^{90}$ because a district court's denial of an injunction request is no barrier to the grant of an exclusion order by the ITC. The result is an end-run around $e$ Bay that allows patent holders to block the defendant's product even without a district court injunction.

\section{II}

\section{EXCLUSION ORDERS AND THE PUBLIC INTEREST}

The ITC statute does not compel the Commission to grant exclusion orders. It states:

If the Commission determines, as a result of an investigation under this section, that there is a violation of this section, it shall direct that the articles concerned, imported by any person violating the provision of this section, be excluded from entry into the United States, unless, after considering the effect of such exclusion upon the public health and welfare, competitive conditions in the United States economy, the production of like or directly competitive articles in the United States, and United States consumers, it finds that such articles should not be excluded from entry. ${ }^{91}$

The Federal Circuit parses the statute to identify four separate public interest factors, ${ }^{92}$ including "(1) the public health and welfare;

89 The divergence is also potentially illegal under international law. Statutory changes to the law in 1995 were meant to cure the statute of the advantages it gave to domestically made goods - specifically a mandatory timetable, parallel proceedings against foreign manufacturers, and the inability of defendants to raise counterclaims - which a General Agreement on Tariffs and Trade (GATT) panel found to be in violation of the Agreement on Trade Related Aspects of Intellectual Property Rights (TRIPS). See Report of the Panel, United States-Section 337 of the Tariff Act of 1930, II 4.2, L/6439 (Nov. 7, 1989), GATT B.I.S.D. (36th Supp.) at 345 (1990). The logic of that case, that certain domestically made goods may be immune from injunctions while international ones are not, could similarly be found to violate national treatment. See id.; see also Comment Regarding the ITC's Notice of Proposed Rulemaking on Its Rules of Practice and Procedure from the Computer \& Commc'ns Indus. Ass'n (Nov. 30, 2010), available at http://www.ccianet.org/CCIA/files/ccLibraryFiles/Filename/00000000552/CCIA\%20Comments $\% 20 I T C \% 20$ Rulemaking\%20MISC-032.pdf (suggesting that the ITC adopt eBay in order to comply with the United States' obligations under Article III:4 of the GATT, as articulated in the panel report United States - Section 337 of the Tariff Act of 1930, supra).

90 Compare, e.g., Paice LLC v. Toyota Motor Corp. (Paice II), 504 F.3d 1293, 1314-15 \& n.14 (Fed. Cir. 2007) (upholding the district court's failure to issue an injunction), with Certain Hybrid Electric Vehicles and Components Thereof, USITC Inv. No. 337-TA-688, 74 Fed. Reg. 52,258 (Oct. 9, 2009) (Preliminary) (Notice of Investigation) (initiating an investigation of the behavior not enjoined by the district court). See also Chien, Protecting Domestic Industries, supra note 70, at 185-86 \& nn.96-102 (describing the situation of Paice II in both the district court and the ITC).

9119 U.S.C. $\S 1337(d)(1)(2006)$.

92 See Spansion, Inc. v. ITC, 629 F.3d 1331, 1358 (Fed. Cir. 2010). 
(2) competitive conditions in the United States economy; (3) the production of like or directly competitive articles in the United States; and (4) United States consumers." 93

Taken together, these factors might seem to give the ITC a fairly wide-ranging power to consider things like patent holdup, the relationship between the patent and the ultimate product, and whether or not the patentee practices the invention. Indeed, the statute directs the ITC to take the public interest into account every time it considers issuing a remedy. ${ }^{94}$

Nonetheless, in the vast majority of section 337 cases, the ITC finds that excluding goods does not threaten the public interest. The ITC has found that the public interest trumped exclusion in only three cases: car parts necessary for improved fuel efficiency, ${ }^{95}$ scientific equipment for nuclear physics research,${ }^{96}$ and hospital burn recovery beds. ${ }^{97}$ The unifying theme in these cases is that the products were necessary for something socially important (human health or some other nationally recognized policy goal), and no other supplier could meet demand in a commercially reasonable time period. ${ }^{98}$ The ITC also decided these cases more than twenty-five years ago. More recently, the ITC has indicated that, unless the contested product is a drug or medical device, it is unlikely to meet the public interest exception. ${ }^{99}$

The ITC views enforcing patents as in the public interest, resulting in

93 Id. (citation omitted)

94 See, e.g., 19 U.S.C. $\S 1337(\mathrm{~d})(1)$ (covering exclusion orders); id. § 1337(f)(1) (covering cease-and-desist orders). Indeed, we believe that the mandate that the ITC "shall" exclude articles "unless" one of the public interest cautions otherwise, as a matter of statutory interpretation, requires their consideration, more so than it does the ITC's remedy. See, e.g., Certain Automated Mechanical Transmission Systems for Medium-Duty and Heavy-Duty Trucks and Components Thereof, Inv. No. 337-TA-503, USITC Pub. 3934, at 7 (May 9, 2005) (Final) (Commission Opinion) ("Section 337(d) and (f) directs the Commission to consider public interest factors before issuing remedial orders, including the effect of any such remedial order on the "public health and welfare, competitive conditions in the United States economy, the production of like or directly competitive articles in the United States, and United States consumers." (citation omitted)).

95 See Certain Automatic Crankpin Grinders, Inv. No. 337-TA-60, USITC Pub. 1022, at 1 (Dec. 17, 1979) (Final) (Commission Determination and Order); see also id. at 17-18 (Opinion of Vice Chairman Alberger and Commissioners Bedell and Stern); infra notes 105-108 and accompanying text (discussing ITC denials of remedies based on the public interest exception).

96 See Certain Inclined-Field Acceleration Tubes and Components Thereof, Inv. No. 337-TA-67, USITC Pub. 1119, at 1, 22-31 (Dec. 29, 1980) (Final) (Commission Action and Order); infra notes 109-111 and accompanying text.

97 See Certain Fluidized Supporting Apparatus and Components Thereof, Inv. No. 337-TA-182/188, USITC Pub. 1667, at 1-2 (Oct. 5, 1984) (Final) (Commission Memorandum Opinion); infra notes 112-118 and accompanying text.

98 See infra notes 105-118 and accompanying text.

99 See Certain Toothbrushes and the Packaging Thereof, Inv. No. 337-TA-391, USITC Pub. 3068, at 6 (Oct. 15, 1997) (Final) (Commission Opinion on Remedy, the Public Interest, and Bonding) ("[T] oothbrushes are not the type of product that have in the past raised public interest concerns (such as, for example, drugs or medical devices)."). 
a thumb on the scale in favor of the patentee in public interest analyses. The Federal Circuit has accepted this approach. In San Huan New Materials High Tech, Inc. v. International Trade Commission, ${ }^{100}$ the Federal Circuit affirmed the ITC's imposition of a significant penalty, saying: "Finally, addressing the "public interest" factor, the Commission determined that the public interest favors the protection of intellectual property rights and weighs in favor of a "significant penalty." 101 And the court has interpreted the legislative history of the ITC statute as supporting exclusion of infringing products: "The legislative history of the amendments to Section 337 indicates that Congress intended injunctive relief to be the normal remedy for a Section 337 violation and that a showing of irreparable harm is not required to receive such injunctive relief." ${ }^{102}$ The Federal Circuit's review of ITC remedies is deferential, ${ }^{103}$ meaning that most of the substantive discussions of the public interest factors occur in ITC decisions, not Federal Circuit decisions.

In the three cases in which the ITC has in fact denied injunctive relief, its focus has been on two of the public interest factors: the public interest in health and welfare and the unavailability of alternatives. It has only denied an exclusion order when both factors are present. ${ }^{104}$

The ITC first denied a remedy on the basis of the public interest exception in Certain Automatic Crankpin Grinders. ${ }^{105}$ The ITC based its decision on the public interest in fuel efficiency, which automobile manufacturers claimed was put in jeopardy without access to the crankpin grinders at issue. ${ }^{106}$ In denying an exclusion order, the ITC noted that the domestic industry could not meet demand in a reasonable length of time and that the president and Congress had a clearly established policy of increasing fuel economy. ${ }^{107}$ The existence of a major oil crisis in 1979 probably also contributed to the decision. ${ }^{108}$

\footnotetext{
100161 F.3d 1347 (Fed. Cir. 1998).

101 Id. at 1363. But cf. Rosemount, Inc. v. ITC, 910 F.2d 819, 822 (Fed. Cir. 1990) ("We also agree with the Commission's rejection of the view that the public interest inevitably lies on the side of the patent owner because of the public interest in protecting patent rights, although that is one factor to consider and may be a dominant factor.").

102 Spansion, Inc. v. ITC, 629 F.3d 1331, 1358 (Fed. Cir. 2010).

103 Id. ("[The Federal Circuit] reviews the Commission's action in awarding injunctive relief as to whether it is arbitrary, capricious, an abuse of discretion, or otherwise not in accordance with law.").

104 See Certain Inclined-Field Acceleration Tubes and Components Thereof, Inv. No. 337-TA-67, USITC Pub. 1119, at 1, 21-31 (Dec. 29, 1980) (Final) (Commission Action and Order); Certain Automatic Crankpin Grinders, Inv. No. 337-TA-60, USITC Pub. 1022, at 17-18 (Dec. 17, 1979) (Final) (Opinion of Vice Chairman Alberger and Commissioners Bedell and Stern).

105 Inv. No. 337-TA-60, at 17-18 (Opinion of Vice Chairman Alberger and Commissioners Bedell and Stern).

106 See id. at 18.

107 See id. at 20.

108 The Commission wrote:
} 
The ITC issued a similar decision the following year in Certain Inclined-Field Acceleration Tubes and Components Thereof. ${ }^{109}$ There, the Commission was confronted with claims of public interest in "pure scientific research and the advancement of knowledge." 110 The ITC concluded that the infringing Dowlish tubes were "greatly superior" and "substantially less expensive" than their counterparts and "indispens[a]ble" to research that was in the public interest. ${ }^{111}$ Thus, as in Crankpin

The primary reason for our determination is that the domestic industry cannot supply the demand for new orders of the patented product within a commercially reasonable length of time. ...

In view of the fact that Congress and the President have also clearly established a policy requiring automotive companies to increase the fuel economy of the automobiles they produce and that some of these companies are encountering difficulties in obtaining automatic crankpin grinders on a timely basis, to produce the statutorily mandated energy efficient automobiles, we believe that it is not in the public interest to provide a remedy in this case. In this period of rapid changes in the energy field, there are overriding public interest considerations in not ordering a remedy which will hamper the supply of energy efficient automobiles. This is not merely a matter of meeting the demands of individual consumers for fuel efficient automobiles. The public as a whole has an interest in conserving fuel through the provision of energy efficient alternatives represented in this case by automobiles with more efficient engines which are produced with the assistance of crankpin grinders which are the subject of this investigation.

Id. at 18,20

109 Inv. No. 337-TA-67, at 1, 22-31 (Commission Action and Order).

$110 \quad I d$. at 21.

111 Id. at 27. The Commission wrote:

We believe that basic scientific research, such as the nuclear structure research conducted with inclined-field acceleration tubes, is precisely the kind of activity intended by Congress to be included when it required the Commission to consider the effect of a remedy on the public health and welfare. ... Although there are few indications in the record of practical applications for nuclear structure physics, it shows that the tubes at Los Alamos are used for nuclear weapons development and the University of Arizona uses them as mass spectrometers for carbon 14 dating, essential to paleontological and archaeological applications. Many scientists would argue, of course, that basic research is intrinsically beneficial regardless of immediate practical application. The support of universities and public agencies is ample support for that proposition.

...

Finally, the President and the Congress have issued declarations of support for basic science research. The National Science Foundation Act, which supports with grants much of the research done with both the domestic and imported tubes, is codified in title 42, United States Code, which is entitled Public Health and Welfare.

$\ldots$

. . The users consider the Dowlish tube to be greatly superior in performance to the High Voltage tube - not to mention substantially less expensive - and therefore indispensible $[s i c]$ to their research efforts. The tubes provide the greater stability of operation and more consistent results essential for accurate research.

....

Once the importance of basic research in nuclear structure physics is 
Grinders, the Commission believed both that the public needed the infringing products for health and welfare reasons and that the products wouldn't be available if it granted the exclusion order.

The final case in which the Commission denied an exclusion order is Certain Fluidized Supporting Apparatus and Components Thereof. ${ }^{112}$ Unlike the other two cases, this case involved denial of temporary relief under 19 U.S.C. $§ 1337(\mathrm{e}) .{ }^{113}$ The ITC noted that this procedural posture allowed it more discretion in framing a remedy, just as district courts have more freedom to deny preliminary injunctions. ${ }^{114}$ Fluidized Supporting Apparatus involved hospital burn recovery beds. ${ }^{115}$ The ITC concluded that the infringing beds "provide[d] benefits unavailable from any other device or method of treatment" and that other suppliers could not meet the demand within a reasonable time. ${ }^{116}$ The Commission affirmed the administrative law judge's finding that "if a temporary exclusion order were issued some patients might not have access to burn beds at all in the interim period," both because of the patentee's higher prices and because of concerns about the ability of the patentee to meet manufacturing demand. ${ }^{117}$ Unlike the others, this case focused more on the public interest in health than on unavailability, but the Commission did find at least partial unavailability. ${ }^{118}$

In contrast to these cases, the Commission has regularly rejected public interest arguments when it finds either that alternative suppliers can't provide comparable products or that the products aren't critical to public health and welfare. For example, the Commission has recognized the public interest in supplying consumers with needed drugs. ${ }^{119}$ However, it has held that if the patentee can supply all domestic demand, there is no public interest problem even if the patentee would satisfy the demand only at a higher price. ${ }^{120}$ Significant public health interests, then, aren't enough

\footnotetext{
established, we are faced with a difficult balance - the impact of a remedy on users of the imported device versus the impact of the violation on the owner of the patent. After weighing these considerations, we determine that public interest factors preclude a remedy in this investigation.

Id. at 22-23, 27, 29 (footnotes omitted).

112 Inv. No. 337-TA-182/188, USITC Pub. 1667 (Oct. 5, 1984) (Final) (Commission Memorandum Opinion).

113 See id. at 1.

114 See id. at 3 ("[I]f the relevant substantive elements are established, the issuance of temporary relief is largely discretionary, while the issuance of permanent relief is mandatory.").

115 Id. at 1.

116 Id. at 23 (quoting SSI Petition for Review at 4, Inv. No. 337-TA-182/188 (Oct. 5, 1984)).

117 See id.

118 See id. at 23-25.

119 See Certain Crystalline Cefadroxil Monohydrate, Inv. No. 337-TA-293, USITC Pub. 2391 (Mar. 21, 1990) (Final) (Commission Opinion on the Issue Under Review, and on Remedy, the Public Interest, and Bonding).

120 Id. at $46-47$.

There is, of course, an additional public interest in maintaining an adequate
} 
to cut against an injunction unless coupled with unavailability.

On the other end of the spectrum, the Commission has held that the unavailability of equivalent products is insufficient grounds to refuse an exclusion order when the products do not affect important health or welfare interests. In Certain Hardware Logic Emulation Systems and Components Thereof, the respondent argued that the patentee's hardware logic emulators weren't an effective substitute because those emulators weren't of the same quality as the respondent's. ${ }^{121}$ The Commission rejected that argument, not by disagreeing with the factual claim, but by concluding that emulators weren't critical to the public interest:

$[\mathrm{H}]$ ardware logic emulators are not the type of product that has in the past raised public interest concerns (such as, for example, drugs or medical devices) and we are not aware of any other public interest concern that would militate against entry of the remedial orders we have determined to issue. ${ }^{122}$

Thus, the confluence of both the unavailability of alternatives and the important nature of the product seems necessary for the Commission to deny an exclusion order. ${ }^{123}$

supply of pharmaceuticals for U.S. consumers. This interest also does not bar relief. Bristol has sufficient capacity and resources to satisfy all domestic demand for cefadroxil, as it had until respondents entered the market in March 1989. Moreover, the availability of other cephalosporins will not be affected by the issuance of relief. The record indicates that Bristol perceives a number of these cephalosporins to be competitive with cefadroxil; that at least one of the competitive cephalosporins, cephalexin, is available in generic form; and that, even if generic cefadroxil were unavailable ... . The record consequently refutes respondents' contention that granting relief will somehow deprive the ill and indigent of necessary medication.

The only remaining argument respondents make is that granting relief will raise prices to consumers. The Commission has previously held that this alone is not sufficient grounds for denying relief.

Id. (alteration in original) (footnotes omitted); see also Certain Gaming and Entertainment Consoles, Related Software, and Components Thereof, Inv. No. 337-TA-752, 2012 ITC LEXIS 1225 (May 7, 2012) (Recommended Determination on Remedy and Bonding) (banning Xbox gaming consoles where the only two competitors could satisfy demand and noting that "there is a strong public interest in enforcing intellectual property rights; not enforcing those rights in light of a potential economic impact occurs only in exceptional circumstances").

121 Inv. No. 337-TA-383, USITC Pub. 2991, at 8 (Oct. 15, 1996) (Commission Opinion on Remedy, the Public Interest, and Bonding).

122 Id. at 9.

123 See Certain Toothbrushes and the Packaging Thereof, Inv. No. 337-TA-391, USITC Pub. 3068, at 6 (Oct. 15, 1997) (Final) (Commission Opinion on Remedy, the Public Interest, and Bonding) ("[T] he public interest favors the protection of U.S. intellectual property rights, the U.S. market for toothbrushes of the type at issue could be supplied by complainant or by noninfringing alternatives, and toothbrushes are not the type of product that have in the past raised public interest concerns (such as, for example, drugs or medical devices)." (footnote omitted)); Certain Processes for the Manufacture of Skinless Sausage Casings and Resulting Product, Inv. No. 337 TA-148/169, USITC Pub. GC-84-187, at 13 (Nov. 9, 1984) (Preliminary) (Review of Initial Determination, Remedy, Bonding, and the Public Interest) ("Sausage casings are not an essential item for the preservation of the public health and welfare."). 
This result might not seem particularly encouraging for the use of the public interest exceptions to combat patent holdup. Patent holdup tends to occur in complex, multicomponent products, particularly in information technology industries. ${ }^{124}$ Holdup is a greater risk in those industries not only because more patents are asserted there but also because those patents tend to cover small parts of much larger products. ${ }^{125}$ A patent that covers the active ingredient in a drug gives the patentee the right to prevent the sale of that drug - that isn't holdup but the patentee's normal right to exclude infringing products. By contrast, a patent on a particular circuit layout may constitute only a tiny fraction of the value of a microprocessor that uses the layout, but an exclusion order will exclude the microprocessor as a whole, preventing the defendant from importing both the small infringing element and the much larger noninfringing elements. The social harm in this latter case is disproportionate to the social benefit, as many productive, noninfringing components will be shut down to give the patentee control over only a single, small component. The ITC cases applying the public interest exception, however, have generally not found much of a public health and welfare interest in information technology products, where the holdup problem is most acute..$^{126}$

Nonetheless, there are reasons to think the application of the public interest factors going forward may be broader than it has been in the past. Notably, the ITC has traditionally focused most of its attention on only a subset of the statutory factors. The Commission has paid close attention to the effect of exclusions on the public health and welfare and the production of like or directly competitive articles in the United States. ${ }^{127}$ In contrast, it has paid very little attention to competitive conditions in the U.S. economy and the effect of exclusions on U.S. consumers. ${ }^{128}$

124 See Fed. TRAde Comm'N, supra note 2, at 3, 35, 160. Indeed, John Turner finds that PAEs depend for their business model on a critical mass of other inventions made by product-producing companies. John L. Turner, Patent Thickets, Trolls and Unproductive Entrepreneurship 3 (Oct. 2011) (unpublished manuscript), available at http://papers.ssrn.com/sol3/papers.cfm?abstract_id=1916798.

125 See, e.g., Mark A. Lemley, Ten Things to Do About Patent Holdup of Standards (and One Not to), 48 B.C. L. REV. 149, 150-51 (2007).

126 See J. Gregory Sidak, The Law and Economics of Section 337 Exclusion Orders for Patent Infringement at the International Trade Commission 49-60 (Criterion Economics LLC, Working Paper Series, 2011) [hereinafter Sidak, Law and Economics] (arguing that the existing public interest analysis at the ITC does not sufficiently take account of the problem of holdup).

127 See supra notes 105-118 and accompanying text.

128 Congress indicated that competitive conditions were intended to be an important part of the public interest analysis:

The Committee believes that the public health and welfare and the assurance of competitive conditions in the United States economy must be the overriding considerations in the administration of this statute. Therefore, under the Committee bill, the Commission must examine (in consultation with other Federal agencies) the effect of issuing an exclusion order or a cease and desist order on the public health and welfare before such order is issued. Should the Commission find that issuing an exclusion order would have a greater adverse 
Today, the mix of cases before the Commission has changed. In a traditional case in which a domestic company sues a foreign counterfeiter, the public interest is clear: ban the importation. But this type of case is less and less common; only $12 \%$ of ITC cases fit the prototypical profile of a domestic plaintiff suing a foreign defendant. ${ }^{129}$ Though section 337 was created to keep foreign pirates out of American markets, recent PAE cases have targeted domestic companies almost twice as often as foreign ones (209 times versus 123 times, respectively). ${ }^{130}$

Cases brought against "knockoffs" are also comparatively rare- $58 \%$ of cases were brought against public companies, which are, for reasons of reputation and brand, unlikely to fit the "counterfeiter" category. ${ }^{131}$ More cases also now fit the PAE profile. ${ }^{132}$ In addition, reversing the traditional roles, foreign patent holders have sought to enjoin domestic companies from importation. In 2011, Beacon Navigation $\mathrm{GmbH}$, a Swiss patent-holding company with few U.S. employees and no products, research, or development related to the accused product (it had purchased patents from another party), ${ }^{133}$ sued all major carmakers for their use of GPS navigation systems. ${ }^{134}$ That same year, MOSAID Technologies Inc., a Canadian PAE with a shell U.S. operation, brought an ITC action against American technology companies accusing infringement of patents it bought from a bankrupt Israeli startup. ${ }^{135}$

In the wake of $e$ Bay and various changes to the ITC statute and case law, PAEs are flocking to the ITC, both because of the relaxed domestic

impact on the public health and welfare; on competitive conditions in the United States economy; on production of like or directly competitive articles in the United States; or on the United States consumer, than would be gained by protecting the patent holder (within the context of the U.S. patent laws) then the Committee feels that such exclusion order should not be issued. This would be particularly true in cases where there is any evidence of price gouging or monopolistic practices in the domestic industry.

S. REP. No. 93-1298, at 197 (1974).

129 Chien, Patently Protectionist, supra note 8 , at $89 \& 89$ tbl.3.

130 Based on an analysis of 332 unique respondents named in PAE suits from January 2011 to June 2012, 123 were from foreign jurisdictions and 209 were from domestic jurisdictions. See infra Appendix A.

131 Chien, Patently Protectionist, supra note 8, at 92 tbl.4.

132 See supra Figure 4.

133 Hearing on the ITC and Patent Disputes, supra note 10, at 3 (statement of David B. Kelley, Intellectual Property Counsel, Ford Global Technologies LLC).

134 Certain Automotive GPS Navigation Systems, Components Thereof, and Products Containing Same, Inv. No. 337-TA-814, 76 Fed. Reg. 72,442 (Nov. 23, 2011) (Preliminary) (Notice of Institution of Investigation).

135 Certain Equipment for Communications Networks, Including Switches, Routers, Gateways, Bridges, Wireless Access Points, Cable Modems, IP Phones, and Products Containing Same, Inv. No. 337-TA-778, 76 Fed. Reg. 36,154 (June 21, 2011) (Preliminary) (Notice of Institution of Investigation); see Hearing on the ITC and Patent Disputes, supra note 10 (statement of Neal A. Rubin, Vice President of Litigation, Cisco Systems, Inc.). 
industry requirement ${ }^{136}$ and because courts are no longer a sure bet for injunctions. ${ }^{137}$ PAEs disproportionately bring cases involving complex, multicomponent technologies. ${ }^{138}$

As a result, the balance of public interest factors is different today than it traditionally has been. First, one of the factors that the Commission has always considered important-whether another company will fill the gap created by exclusion - is less likely to be satisfied when the complainant doesn't practice the patent. That is especially true when the patentee complains against a host of companies at once, as is often the case in PAE actions. ${ }^{139}$ If the patentee claims that the entire industry infringes, all producers will be subject to the exclusion order, and thus no company will be available to fill market demand. ${ }^{140}$

Second, both competitive conditions and consumers are affected to a greater degree by the grant of exclusion orders in complex, multicomponent cases than in traditional counterfeiter cases. Exclusion orders affect not just the supply of the infringing feature but also the price and supply of noninfringing features and functionalities, the customers and third parties who rely on these noninfringing features, and-through the mechanism of holdup - the research and development activities of companies that make the noninfringing components. ${ }^{141}$ Patent holdup was not a feature of most ITC actions until recently because PAEs didn't sue entire industries and suits didn't usually involve complex, multicomponent products. ${ }^{142}$ The changed circumstances permit the ITC to take a different

\footnotetext{
136 See Czebiniak, supra note 8, at 110.

137 See eBay Inc. v. MercExchange, L.L.C., 547 U.S. 388, 391 (2006).

138 Eighty-six percent of ITC cases filed by NPEs between 2005 and 2011 were in high-tech sectors. See Michael Kallus \& James Conlon, RPX Corp., International Trade Commission: The Second Theater 16-17 (Oct. 3, 2011) (on file with authors) (showing that $86 \%$ of ITC NPE cases involved mobile communications, semiconductors, consumer electronics, PCs, networking, storage, software, or ecommerce technologies, in contrast to ITC cases in general, $63 \%$ of which involved these sectors).

139 See supra Figure 2

140 The issue is more complex when the patentee sues an entire industry but settles by licensing its patent to some parties before trial. In that case, some parties will be able to sell licensed products even if an exclusion order issues against the remaining defendants. But saying that whether a patentee can exclude defendants should depend on whether other defendants choose to go to trial seems odd. District courts after $e$ Bay have been unwilling to view nonexclusive licenses granted in settlement of patent disputes as evidence of irreparable injury justifying injunctive relief. See z4 Techs., Inc. v. Microsoft Corp., 434 F. Supp. 2d 437, 440 (E.D. Tex. 2006). The same logic might apply here.

141 See, e.g., Certain Baseband Processor Chips and Chipsets, Transmitter and Receiver (Radio) Chips, Power Control Chips, and Products Containing Same, Including Cellular Telephone Handsets, Inv. No. 337-TA-543, USITC Pub. 4258, at 1 (June 7, 2007) (Final) (Order to Cease and Desist) (restricting Qualcomm's research, development, and testing of broadband base processors); see also id. at 154 (June 19, 2007) (Final) (Commission Opinion on Remedy, the Public Interest, and Bonding) (rejecting Qualcomm's position that a cease-and-desist order would impair the public interest).

142 See supra Part I.
} 
approach.

Recent ITC action suggests that the Commission may be open to rethinking its public interest case law. The ITC has received more attention from Congress ${ }^{143}$ and other agencies and, as a result, is more cognizant of the context of its actions. In 2011, the ITC incorporated public interest considerations into its decision not to deny, but instead to delay the start of, an exclusion order in a case involving smartphones. ${ }^{144}$ Around that time, the ITC changed its rules to allow an administrative law judge, under Commission order, to take evidence on the public interest at the outset of a case rather than waiting until the end. ${ }^{145}$ The information gathered through this process could be used to identify likely remedies earlier in the proceedings, leading to more efficient resolution of cases.

We applaud this new-found flexibility. In the next Part, we offer specific suggestions for how the Commission could update the public interest considerations for the new, post-eBay world.

\section{III}

\section{TAILORING, BONDING, AND PAUSING IN THE PUBLIC INTEREST}

Remedies in the ITC might seem to be an all-or-nothing affair: the ITC can't award damages; it can only exclude products. ${ }^{146}$ As a result, even judges and Commissioners who believe an exclusion order is not in the public interest might hesitate to apply the public interest standard to deny relief for fear that the patentee will win its case but receive no remedy at all. That fear has always been somewhat overstated; patentees can file suit in district court in parallel with the ITC (and do so two-thirds of the time $^{147}$ ) and may be entitled to an award of damages in court even if neither the ITC nor the court enjoins the sale of the defendant's product. ${ }^{148}$ But

143 See sources cited supra note 10; see also Certain Wireless Communication Devices, Portable Music and Data Processing Devices, Computers and Components Thereof, Inv. No. 337-TA-745, 77 Fed. Reg. 58,576, at 1-2 \& n.4 (June 6, 2012) (Preliminary) (Third Party United States Federal Trade Commission's Statement on the Public Interest), available at http://www.ftc.gov/os/2012/06/1206ftcwirelesscom.pdf (noting that Congress required that the ITC "consult with, and seek advice and information from . . . the Federal Trade Commission ... . as it considers appropriate" (quoting 19 U.S.C. $\$ 1337$ (b)(2) (internal quotation marks omitted)).

144 Certain Personal Data and Mobile Communications Devices and Related Software, Inv. No. 337-TA-710, USITC Pub. 4331, at 3 (Dec. 19, 2011) (Final) (Limited Exclusion Order); see also Chien \& Lemley, supra note 7 (recommending this very tailoring remedy in that case).

14519 C.F.R. $\S 210.8, .10$ (b), .14(f), .42(a)(1)(ii)(C), .50(a)(4) (2012).

146 See 19 U.S.C. $\$ 1337$ (2006); Chien, Patently Protectionist, supra note 8, at 102.

147 Chien, Patently Protectionist, supra note 8, at 70 ("'Sixty-five] percent of the ITC cases studied had a district court counterpart ....").

148 In the case of copending ITC and district court cases, the district court case shall be stayed upon a timely request. See 28 U.S.C. $§ 1659$ (a) (2006) ("[The] district court shall stay, until the determination of the Commission becomes final, proceedings in the civil action with respect to any claim that involves the same issues involved in the proceeding before the Commission ....."). The ITC's findings are not accorded res judicata by the courts. Tex. Instruments Inc. v. Cypress Semiconductor Corp., 90 F.3d 1558, 1568-69 (Fed. Cir. 1996). Yet, 
that may be cold comfort to patentees who have wasted the time and effort of going to the ITC only to have the Commission give them no remedy. And the Commission may understandably be reluctant to condemn itself to seeming irrelevance.

While the ITC's remedies seem limited, we think that the Commission has more flexibility than previously recognized. Historically, the ITC has demonstrated flexibility at several points by restricting the relief given to patentees. In 1981, the Commission created a limited exclusion order to supplement the remedy of a general order as "a limitation on the relief afforded a prevailing complainant." ${ }^{149}$ It did so while determining the proper scope of an injunction, even though "Congress ha[d] never specifically authorized the Commission to issue limited exclusion orders as the final remedy in a section 337 investigation." 150 In Certain Erasable Programmable Read-Only Memories, Components Thereof, Products Containing Such Memories, and Processes for Making Such Memories $(E P R O M s)$, the Commission devised a special nine-factor test to apply

in practice, the district courts are expected to reach a similar result on the same claims and explain and distinguish the ITC decision if they don't.

The timing of claims may affect the nature of the remedies. The ITC has held that it has no power to grant an exclusion order if a district court has already awarded an ongoing royalty on the same patent; the ongoing royalty serves as a license. Certain Video Displays and Products Using and Containing Same, Inv. No. 337-TA-828, 2012 ITC LEXIS 1884, at*21-27 (Aug. 1, 2012) (Final) (Order No. 9). But because district court cases must be stayed pending ITC actions, it is rare that the ITC action comes after a district court ruling.

149 See Certain Erasable Programmable Read-Only Memories, Components Thereof, Products Containing Such Memories, and Processes for Making Such Memories, Inv. No. 337-TA-276, USITC Pub. 2196, at 124 n.159 (May 1989) (Final) (Commission Opinion on Violation, and Remedy, Bonding, and the Public Interest). The ITC explains:

[T] he limited exclusion order is itself a limitation on the relief afforded a prevailing complainant, created by the Commission without specific authority in the statute. Congress has never specifically authorized the Commission to issue limited exclusion orders as the final remedy in a section 337 investigation, although it has specifically authorized them when directed at defaulting respondents. Nevertheless, the Commission has been issuing limited exclusion orders since 1981. In light of the extensive attention devoted to section 337 in the past two years, resulting in the amendments effected by the OTCA, we believe it is reasonable to infer Congressional acquiescence in the Commission's practice of issuing limited exclusion orders from Congress' silence on the matter. This is particularly so, since with respect to remedy matters, Congress noted the Commission's belief that it was precluded from issuing both exclusion and cease and desist orders with respect to the same unfair act, and provided specific authority for the Commission to do so, presumably in order to expand the extent of relief available to a prevailing complainant. Had Congress objected to the issuance of limited rather than general exclusion orders as insufficient relief, it would presumably have acted to limit the Commission's authority to issue such orders.

Id.

150 Id. In general, an administrative agency's latitude to craft appropriate remedies, while not unlimited, is broad. See Jacob Siegel Co. v. FTC, 327 U.S. 608, 613 (1946) ("[T] he courts will not interfere except where the remedy selected has no reasonable relation to the unlawful practices found to exist."). 
when an exclusion order implicated so-called "downstream products"products that incorporated the infringing component. ${ }^{151}$ This test reflects, in large part, a concern about the proportionality of the ITC remedy to the "wrong" of patent infringement as reflected in Factor 1 ("the value of the infringing articles compared to the value of the downstream products in which they are incorporated"), Factor 3 ("the incremental value to the complainant of the exclusion of downstream products"), Factor 4 ("the incremental detriment to respondents" of exclusion of such products), and Factor 5 ("the burdens imposed on third parties resulting from exclusion of downstream products"). ${ }^{152}$ When the value of the invention is small compared to the value of the enjoined article that incorporates the invention downstream, the ITC has paused to consider whether the patentee deserves an injunction and if so, what type of injunction is appropriate. ${ }^{153}$

Although the nine-factor test has arguably diminished in importance with the Federal Circuit's decision in Kyocera Wireless Corp. $v$. International Trade Commission, ${ }^{154}$ the concerns about undue interference with the market that prompted it endure. High-tech component cases are now the norm at the ITC: $86 \%$ of ITC cases filed by NPEs between 2005 and 2011 were in high-tech sectors. ${ }^{155}$ In this Part, we suggest some ways in which the ITC can use its discretion to craft remedies consistent with the statute's public interest provisions and the Commission's EPROMs test.

Much of the ITC's potential flexibility derives from 19 U.S.C. $§ 1337$,

151 Inv. No. 337-TA-276, USITC Pub. 2196, at 124-26 (Final) (Commission Opinion on Violation, and Remedy, Bonding, and the Public Interest). The nine factors in this limited exclusion order require the ITC to evaluate:

(1) "the value of the infringing articles compared to the value of the downstream products in which they are incorporated";

(2) "the identity of the manufacturer of the downstream products" (i.e., whether it can be determined that the downstream products are manufactured by the respondent or by a third party);

(3) "the incremental value to the complainant of the exclusion of downstream products";

(4) "the incremental detriment to respondents" of exclusion of such products;

(5) "the burdens imposed on third parties resulting from exclusion of downstream products";

(6) "the availability of alternative downstream products which do not contain the infringing articles";

(7) "the likelihood that imported downstream products actually contain the infringing articles and are thereby subject to exclusion";

(8) "the opportunity for evasion of an exclusion order which does not include downstream products"; and

(9) "the enforceability of an order by Customs, etc."

Id. at 125 .

152 Id.

153 See, e.g., id. at 127.

154545 F.3d 1340, 1357-58 (Fed. Cir. 2008). Kyocera prohibited the exclusion of downstream products through a limited exclusion order, so the EPROMs test no longer applies there. For a discussion of Kyocera, see generally Cotropia, supra note 87.

155 Kallus \& Conlon, supra note 138, 16-17. 
which gives the Commission broad discretion to fashion an appropriate remedy. ${ }^{156}$ Additionally, the Federal Circuit is largely deferential to the ITC's remedy determinations, reversing them only when they are "arbitrary, capricious, an abuse of discretion, or otherwise not in accordance with law." 157 This standard of review is less stringent than the one that applies to the ITC's substantive patent law determinations. ${ }^{158}$

The structure of the ITC's process also provides some flexibility. Once the Commission finds a violation, it is entitled to enter an exclusion order keeping infringing products out of the market. ${ }^{159}$ In some circumstances, the Commission holds a separate hearing after a liability finding to determine whether and what particular form of injunctive relief is appropriate. ${ }^{160}$ Assuming the case warrants an exclusion order (and, as noted above, ${ }^{161}$ the Commission essentially always finds that it does), the order is then subject to a sixty-day presidential review period. ${ }^{162}$ But the exclusion order goes into effect immediately-before the presidential review period - unless the respondent posts a bond adequate to compensate for sales made during the review period. ${ }^{163}$ And once the Commission's

156 See 19 U.S.C. $\S 1337$ (c) (2006) (“Commission determinations . . . with respect to its findings on the public health and welfare, competitive conditions in the United States economy, the production of like or directly competitive articles in the United States, and United States consumers, the amount and nature of bond, or the appropriate remedy shall be reviewable in accordance with section 706 of title 5."); 5 U.S.C $\$ 706$ (2006) ("The reviewing court shall . . hold unlawful and set aside agency action, findings, and conclusions found to be . . arbitrary, capricious, an abuse of discretion, or otherwise not in accordance with law ...."); Hyundai Elecs. Indus. Co. v. ITC, 899 F.2d 1204, 1208 (Fed. Cir. 1990) (finding, based on a review of Section 337's legislative history, that 5 U.S.C. $\$ 706(2)(A)$ governs the Federal Circuit's review of ITC remedy determinations); accord Spansion, Inc. v. ITC, 629 F.3d 1331, 1358 (Fed. Cir. 2010) (citing Epistar Corp. v. ITC, 566 F.3d 1321, 1333 (Fed. Cir. 2009)).

157 See Spansion, 629 F.3d at 1358 (citing Epistar, 566 F.3d at 1333); Hyundai, 899 F.2d at 1208; see also Kyocera, 545 F.3d at 1355 (applying the framework established by Chevron U.S.A. Inc. v. Natural Resources Defense Council, Inc., 467 U.S. 837 (1984), to an ITC order and stating that if "the statute in question is ambiguous and the agency's interpretation is reasonable, a court must defer to an agency's construction of a statute governing agency conduct" (quoting Cathedral Candle Co. v. ITC, 400 F.3d 1352, 1361 (Fed. Cir. 2005)) (internal quotation marks omitted)).

158 Hyundai, 899 F.2d at 1208 ("Congress . . . desire[d] to subject Commission determinations on the public interest, . . . bonding, and remedy, to a less stringent standard of judicial review than determinations of substantive violations of section 337.").

15919 U.S.C. $\$ 1337(\mathrm{e})(1)$.

160 Certain Personal Data and Mobile Communications Devices and Related Software, Inv. No. 337-TA-710, USITC Pub. 4331, at 3-7 (July 15, 2011) (Final) (Commission Opinion).

161 See supra Figure 3.

16219 U.S.C. $\S 1337(j)(2)$ ("If, before the close of the 60-day period beginning on the day after the day on which he receives a copy of such determination, the President, for policy reasons, disapproves such determination and notifies the Commission of his disapproval, then, effective on the date of such notice, such determination and the action taken under subsection (d), (e), (f), (g), or (i) of this section with respect thereto shall have no force or effect.").

163 Id. $\S 1337(\mathrm{e})(1)$ ("The Commission shall notify the Secretary of the Treasury of its action under this subsection directing such exclusion from entry, and upon receipt of such notice, the Secretary shall, through the proper officers, refuse such entry, except that such articles shall be 
order is final, the respondent can appeal to the Federal Circuit. ${ }^{164}$

This process creates three remedies that are less harsh than simply excluding products but more powerful than simply denying an injunction. First, the ITC can decide what its exclusion order will cover. It can choose - and indeed has chosen ${ }^{165}$ — to include certain products and exclude others in its orders. Second, the ITC can decide when it will implement its exclusion order. It doesn't have to choose between immediately enjoining the product or doing nothing; it can delay the order or apply it only prospectively. Finally, the ITC can use its statutory authority to set a bond to permit continued importation during the review period but condition that importation on the payment of money. Small tweaks to these aspects of how the ITC awards injunctions can potentially yield big benefits to the public interest, as we explain below.

\section{A. Grandfathering and Tailoring Injunction Scope}

The statute directs the Commission to exclude infringing articles unless public interest concerns dictate otherwise. ${ }^{166}$ Read with an eye toward tailoring, the provision essentially requires the Commission to fashion its exclusion orders so that they will pass public interest muster. An exclusion order tells a company to stop importing its product, ${ }^{167}$ but the ITC can soften the harshness of this remedy by grandfathering in existing models or units. When the product remains available in some form and the exclusion order applies only to future versions or units of the product, consumers and competition are less likely to suffer.

The ITC has engaged in this kind of tailoring in response to these types of public interest concerns. In Certain Baseband Processor Chips and Chipsets, Transmitter and Receiver (Radio) Chips, Power Control Chips, and Products Containing Same, Including Cellular Telephone Handsets, the Commission found that the requested full-scale exclusion order was "not permitted in [the] investigation" due to the potential harm to third parties. ${ }^{168}$ However, the Commission granted an adjusted exclusion

\footnotetext{
entitled to entry under bond prescribed by the Secretary in an amount determined by the Commission to be sufficient to protect the complainant from any injury. If the Commission later determines that the respondent has violated the provisions of this section, the bond may be forfeited to the complainant."); id. § 1337(j)(3) ("[A]rticles directed to be excluded from entry under subsection (d) of this section or subject to a cease and desist order under subsection (f) of this section shall, until such determination becomes final, be entitled to entry under bond prescribed by the Secretary in an amount determined by the Commission to be sufficient to protect the complainant from any injury. If the determination becomes final, the bond may be forfeited to the complainant. The Commission shall prescribe the terms and conditions under which bonds may be forfeited under this paragraph.").

164 Id. § 1337(c).

165 See infra Part III.A.

16619 U.S.C. $\$ 1337(d)$.

16719 U.S.C. $\$ 1337(d)(1)$.

168 Certain Baseband Processor Chips and Chipsets, Transmitter and Receiver (Radio) Chips,
} 
order that grandfathered in existing models of handsets. ${ }^{169}$ The grandfathering exemption caused the exclusion order to "adequately address public interest concerns," which allowed the Commission to issue the order. ${ }^{170}$

The Commission has tailored exclusion scope in other cases as well. In Personal Data and Mobile Communications Devices, the Commission grandfathered refurbished replacement handsets into its exclusion order, ${ }^{171}$ and in Certain Sortation Systems, Parts Thereof, and Products Containing Same 172 and Certain Automated Mechanical Transmission Systems for Medium-Duty and Heavy-Duty Trucks and Components Thereof, ${ }^{173}$ the ITC exempted from its exclusion order spare parts to service existing systems and facilities, citing the exemption in its public interest analysis. Given these precedents, we believe the ITC could use grandfathering and related exemptions in appropriate circumstances to protect consumer access to the noninfringing portions of complex, multicomponent products. ${ }^{174}$

\section{B. Delay}

The Commission may also choose in certain circumstances to delay the implementation of exclusion orders. ${ }^{175}$ The Commission normally imposes an exclusion order immediately, though, as noted above, the respondent can effectively stay an injunction for sixty days by posting a bond. ${ }^{176}$ The respondent may also be able to obtain a stay of the exclusion

Power Control Chips, and Products Containing Same, Including Cellular Telephone Handsets, Inv. No. 337-TA-543, USITC Pub. 4258, at 153 (June 19, 2007) (Final) (Commission Opinion on Remedy, the Public Interest, and Bonding).

169 Id. at $150-51$.

170 Id. at 150.

171 Certain Personal Data and Mobile Communications Devices and Related Software, Inv. No. 337-TA-710, USITC Pub. 4331, at 83 (July 15, 2011) (Final) (Commission Opinion) ("HTC shall be permitted to import into the United States [for nineteen months] refurbished handsets to be provided to consumers as replacements ....").

172 Inv. No. 337-TA-460, USITC Pub. 3588, at 2 (Jan. 27, 2003) (Preliminary) (Notice of Violation of Section 337 of the Tariff Act of 1930 and Issuance of Limited Exclusion Order) ("The Commission determined to include an exemption in the limited exclusion order for importations of spare parts for United Parcel Service's Hub 2000 facility in Louisville, Kentucky.").

173 Inv. No. 337-TA-503, USITC Pub. No. 3934, at 3 (Apr. 7, 2005) (Final) (Termination of Investigation; Issuance of a Limited Exclusion Order and a Cease and Desist Order) ("The limited exclusion order does not cover parts necessary to service infringing automated mechanical transmission systems installed on trucks prior to the issuance of the order.")

174 See generally Golden, Injunctions, supra note 28 (discussing the scope of injunctions issued in patent infringement cases).

175 Personal Data, Inv. No. 337-TA-710, at 81 (Commission Opinion) ("T-Mobile itself has advised the Commission that a four-month transition period would likely be sufficient .... We find T-Mobile's suggestion to be reasonable and within our authority to implement." (citations omitted)).

17619 U.S.C. $\S 1337(\mathrm{e})(1)(2006)$. 
order pending appeal to the Federal Circuit. ${ }^{177}$ But even if neither occurs, the Commission has the power to delay the implementation of the exclusion order. The ITC could do so in order to give the respondent time to design around the patent or substitute noninfringing products for goods in the pipeline, or to ensure that consumers aren't left without products until the patentee can ramp up production.

Delaying injunctive relief has the potential to significantly ameliorate the holdup problem. As Mark Lemley and Carl Shapiro have shown, holdup is a result of two factors: that an injunction will prevent the sale of noninfringing as well as infringing components in a complex multicomponent product and that roughly three-fourths of litigated patents are either invalid or not infringed. ${ }^{178}$ The fact that an injunction will shut down noninfringing matter means that it costs the respondent more than the patent itself is worth. ${ }^{179}$ Rather than pay that extra cost in settlement, the respondent will sometimes design around the patent to avoid the effect of an injunction. ${ }^{180}$ But because most patent suits lose, most advance designarounds are wasted effort. ${ }^{181}$ The patentee can opportunistically capture the cost of design-around in settlement, even if the patent is likely to be invalid or not infringed. ${ }^{182}$

Delaying the onset of an injunction or exclusion order changes the dynamic. As Lemley and Shapiro show, respondents who can count on a delay to allow them to design around the patent don't need to invest in unnecessary design-arounds to avoid the risk of injunction holdup. ${ }^{183}$ As a

\footnotetext{
177 Id. $\S 1337(\mathrm{c})$.

178 Lemley \& Shapiro, supra note 13, at 1996, 2019 \& n.71. A number of scholars have
} tried to attack this holdup analysis. See Einer Elhauge, Do Patent Holdup and Royalty Stacking Lead to Systematically Excessive Royalties?, 4 J. COMPETITION L. \& ECON. 535, 535-40 (2008); J. Gregory Sidak, Holdup, Royalty Stacking, and the Presumption of Injunctive Relief for Patent Infringement: A Reply to Lemley and Shapiro, 92 MINN. L. REV. 714, 718-20 (2008). But those attacks miss the mark; rather than demonstrate that holdup doesn't exist, these scholars have uniformly argued that patentees deserve the holdup value of their patents, asserting that patentees - unlike everyone else in a market economy-should be paid the full social value of their invention. See Thomas F. Cotter, Patent Holdup, Patent Remedies, and Antitrust Responses, 34 J. CORP. L. 1151, 1153-54, 1162-71 (2009). John Golden has taken a different tack, arguing that it is unfair to treat PAEs differently than product-producing plaintiffs. John M. Golden, "Patent Trolls" and Patent Remedies, 85 TEX. L. REV. 2111, 2147-60 (2007) [hereinafter Golden, Patent Trolls]. But that too misses the point; if one patient needs a kidney and another doesn't, it isn't discrimination to give a kidney only to the one who can show need for it. Similarly, granting injunctions only to parties who can prove they will suffer irreparable injury without it isn't discrimination even though it has different effects on different plaintiffs. See Mark A. Lemley \& Carl Shapiro, Reply: Patent Holdup and Royalty Stacking, 85 TeX. L. REV. 2163, 2163-65, 2169 (2007).

179 Mark A. Lemley \& Philip J. Weiser, Should Property or Liability Rules Govern Information?, 85 TEX. L. REV. 783, 794-95 (2007).

180 See Lemley \& Shapiro, supra note 13, at 2002.

181 See id. at 2019 n.71.

182 See id. at 2002, 2005.

183 See id. at 2038; accord Golden, Patent Trolls, supra note 178, at 2131. 
result, they don't need to pay the owners of weak patents premiums to avoid spending on design-arounds. They can design around the patent only if it becomes necessary to do so. Design-arounds take time- not only to devise, test, and implement in the manufacturing process but sometimes also to gain any necessary regulatory approval. A transition period softens the blow of pulling a product from the market. The Federal Circuit acknowledged this in Broadcom Corp. v. Qualcomm Inc., remarking that "sunset provisions mitigate the harm to the public" as a remedy that protects rights "while allowing... time to develop noninfringing substitutes."184

A delay to allow design-around has another benefit as well: it can help distinguish between patents that really are critical and those that aren't. Giving a respondent, say, six months to design around the patent provides a sort of acid test of the claim that the patent is in fact necessary to practice the invention. If the respondent can design around the patent in six months, the invention it embodies arguably wasn't that valuable, and it probably isn't worth holding up the entire product for a patent that was essentially optional. By contrast, if the respondent can't design around the patent and still sell a product economically, the patent really is valuable, and arguably we should worry less about the risk of holdup caused by the exclusion order. And unlike the district courts with their limited Article III jurisdiction, the ITC has the power to issue advisory opinions as to whether a design-around also infringes the patent, ${ }^{185} \mathrm{a}$ fact that can save a great deal of cost and uncertainty in subsequent litigation. ${ }^{186}$

Patentees might object that delaying the injunction is unfair to them because if the respondent can design around the patent, the patentee will receive nothing. But if the design-around costs more than the original product, the parties should be able to settle for the difference in valuewhich is really the value of the patent in the first place. And if the design-around is easy and just as cheap, the actual value of the patented

184543 F.3d 683, 701, 704 (Fed. Cir. 2008) (approving a district court's injunction that included a twenty-month "sunset provision" that reduced harm to the public interest); Verizon Servs. Corp. v. Vonage Holdings Corp., 503 F.3d 1295, 1311 n.12 (Fed. Cir. 2007) (noting, in dicta, the benefits of a work-around period, though one was not requested by the defendant); see also Golden, Injunctions, supra note 28, at 1461 n.261 (noting and describing cases in which courts have delayed injunctions to avoid the "special disruption" of immediately entered injunctions).

185 Eaton Corp. v. United States, 29 Ct. Int'1 Trade 1149, 1152 (Ct. Int'1 Trade 2005) (noting this option); 19 C.F.R. $\$ 210.79$ (2012). For a discussion of the strategic considerations that go into deciding whether to seek such an opinion, see Merritt R. Blakeslee \& Christopher V. Meservy, Seeking Adjudication of a Design-Around in Section 337 Patent Infringement Investigations: Procedural Context and Strategic Considerations, 35 AIPLA Q.J. 385, 408-11 (2007).

186 Indeed, in Ninestar Technology Co. v. International Trade Commission, the Federal Circuit chastised the respondent for not taking advantage of this procedure before implementing its alleged design-around. 667 F.3d 1373, 1384-85 (Fed. Cir. 2012). 
technology is zero; any payment to the patentee in that case is a windfall.

The ITC has started to recognize the benefits of staying exclusion orders. In Certain Personal Data and Mobile Communications Devices and Related Software, the Commission found that the immediate exclusion of the infringing devices "would not be in the public interest" because of its impact on market competition. ${ }^{187}$ A four-month period of exclusion, however, would provide time for replacement handsets to be devised and provided to customers. ${ }^{188}$ The Commission tailored its injunction accordingly, explaining that "competitive conditions in the United States do not weigh against the issuance of an exclusion order, but favor providing a transition period." 189

As this case demonstrates, incorporating a delay allows the ITC to award exclusion orders where the public interest might dictate otherwise. And there may be a way to compensate patentees for the value of their technology during the period of stay. This possibility relates to the final area of remedial flexibility at the ITC: monetary relief.

\section{Bonds and Penalties}

Although the ITC doesn't routinely award stays, it does routinely sanction the continued importation of articles even after they have been found to be infringing. While the ITC can't award damages, 19 U.S.C. $\S 1337(\mathrm{j})(3)$ authorizes it to set a bond that the respondent can post to allow continued importation through the sixty-day presidential review period. ${ }^{190}$ The amount of the bond must be "sufficient to protect the complainant from any injury," ${ }^{191}$ and it is typically based on the difference in price between complainant's product and the infringing imports. ${ }^{192}$ Requiring respondents to post a bond to delay implementation of the exclusion order pending the presidential review period is effectively a payment of an ongoing royalty.

Because the president essentially never reverses an ITC decision, ${ }^{193}$ respondents almost always forfeit the bond. They pay an ongoing royalty

\footnotetext{
187 Certain Personal Data and Mobile Communications Devices and Related Software, Inv. No. 337-TA-710, USITC Pub. 4331, at 81 (July 15, 2011) (Final) (Commission Opinion) (“[The] immediate exclusion of HTC [devices] would have a substantial impact on T-Mobile's competitiveness ....").

188 See id.

189 Id. at 83.

190 See 19 U.S.C. § 1337(j) (2006); A LAWYER's GUIDE TO SECTION 337 INVESTIGATIONS

BEFORE THE U.S. INTERNATIONAL TRADE COMMISSION, supra note 67, at 186 n.41.

19119 U.S.C. $\$ 1337(\mathrm{j})(3)$.

192 Personal Data, Inv. No. 337-TA-710, at 85 (Commission Opinion).

193 The White House has only ever done so five times. See, e.g., A LAWYER's GUIDE TO SeCtion 337 InVESTIGATIONS Before the U.S. InTERnAtional TRADE COMMission, supra note 67 , at $187-88 \&$ n. 45 . As of 2005 , the White House delegated this power to the U.S. Trade Representative. Assignment of Certain Functions Under Section 337 of the Tariff Act of 1930, 70 Fed. Reg. 43,251 (July 26, 2005)
} 
for the privilege of continuing to sell their products for another sixty days. And if the bond is set correctly, it will mimic the amount of an ongoing royalty in district court, which is the value of the patent based on the number of goods sold. ${ }^{194}$ There is no policy reason the ITC shouldn't be allowed to impose a delay longer than sixty days in exchange for payment of a comparably higher bond. The ITC could stay the order pending appeal, for instance, subject to a bond.

The amount of the bond would depend on the equities of the case. In Personal Data and Mobile Communications Devices, where implementation of the exclusion order was delayed by four months, the ITC entered a bond amount of zero, ${ }^{195}$ although in other cases it may be more. ${ }^{196}$ Combining a delay in the implementation of an exclusion order with a bond compensating the patentee for the value of the invention during the period of delay would allow the ITC to approximate the power a district court has to deny or stay injunctive relief while ordering payment of an ongoing royalty. ${ }^{197}$ This combination will often be the best possible remedy, and certainly it is preferable to the other apparent options: patent holdup by an immediate exclusion order or no remedy at all.

Implementing bond periods longer than sixty days may require some

194 On the calculation of ongoing royalties in district court, see Mark A. Lemley, The Ongoing Confusion over Ongoing Royalties, 76 Mo. L. REV. 695, 701-02 (2011).

195 The opinion suggests that the amount could have been higher had Apple presented better evidence of the price differential. Personal Data, Inv. No. 337-TA-710, at 85 (Commission Opinion) ("Apple failed to satisfy its burden ....”).

196 The amount of the bond is often set at $100 \%$. See, e.g., Certain Radio Control Hobby Transmitters and Receivers and Products Containing Same, Inv. No. 337-TA-763, 2011 ITC LEXIS 1927, at *2 (Sept. 27, 2011) (Final) (Limited Exclusion Order); Certain Toner Cartridges and Components Thereof, Inv. No. 337-TA-740, 2011 ITC LEXIS 1930, at*12-13 (Sept. 27, 2011) (Final) (Cease and Desist Order); Certain Birthing Simulators and Associated Systems, Inv. No. 337-TA-759, 2011 ITC LEXIS 2125, at*3 (Aug. 29, 2011) (Final) (Limited Exclusion Order). In many cases this amount of bond would seem to be far more than "sufficient to protect the complainant from any injury," as provided in 19 U.S.C. $§ 1337(\mathrm{j})(3)$, especially when the invention is a small component of the infringing article. The 2012 order excluding Motorola phones, by contrast, set a bond of thirty-three cents per phone, reflecting the relatively small role the patented invention played in the value of the imported phone, which is worth several hundred dollars. Certain Mobile Devices, Associated Software, and Components Thereof, 337-TA-744, 2012 ITC LEXIS 1042, at *6-7 (May 18, 2012) (Final) (Notice of a Commission Final Determination of Violation of Section 337; Issuance of a Limited Exclusion Order; Termination of Investigation).

One complication for bonding, both under our proposal and existing practice, arises with the growth of NPEs at the ITC. If the patentee doesn't sell the patented invention, there is no price differential to use as a baseline to measure the value of the patent. But district courts confront valuation problems all the time with the help of economists, and the mechanisms they use for apportionment of the value of complex products may also be used at the ITC to set the amount of a bond in an NPE case.

197 The analogy isn't perfect; a bond is presumably set against the possibility of some contingent future event, however unlikely. The power to order payment of a bond might not extend to the power to order the payment of money directly to the complainant with no hope of recovery. But conditioning a bond on something like an appeal will generally achieve the same result. 
creativity, however. Section 1337(j)(3) seems to contemplate that the bond must terminate at the end of the presidential review period, when the Commission's order becomes "final," even though that final order will still be subject to appeal. ${ }^{198}$ One possibility is to change this statutory language to give the ITC more flexibility in determining the length of time covered by a bond. Another, simpler possibility is for the ITC to wait to publish its final notice of finding of violation in the Federal Register until after the delay period ends. By making a preliminary holding rather than a published "determination," the ITC may be able to delay the beginning of the sixty-day clock for presidential review. ${ }^{199}$

The ITC's authority to assess and impose civil penalties for violations of its orders provides another option for the ITC to provide a monetary component to its remedy, even in spite of its inability to award damages. ${ }^{200}$ The ITC has wide latitude in setting penalties, which are reviewed for an abuse of discretion. ${ }^{201}$ In San Huan New Materials High Tech, Inc. v. International Trade Commission, the Federal Circuit endorsed the ITC's approach to setting penalties based on:

(1) the good or bad faith of the respondent; (2) any injury due to the infringement; (3) the respondent's ability to pay the assessed penalty; (4) the extent to which the respondent benefitted [sic] from its violations; (5) the need to vindicate the authority of the Commission; and (6) the public interest. ${ }^{202}$

The Commission's approach to determining the amount of penalty "[takes] into account the 'three overarching considerations enumerated by

\section{U.S.C. $\$ 1337(c)(2006)$.}

19919 U.S.C. $\S 1337(\mathrm{j})(1)$ provides that the sixty-day review period begins when the Commission publishes its determination in the Federal Register and transmits the finding to the President; the order becomes final sixty days thereafter.

200 See 19 U.S.C. § 1337(f)(2) (“Any person who violates an order issued by the Commission under paragraph (1) after it has become final shall forfeit and pay to the United States a civil penalty for each day on which an importation of articles, or their sale, occurs in violation of the order of not more than the greater of $\$ 100,000$ or twice the domestic value of the articles entered or sold on such day in violation of the order. Such penalty shall accrue to the United States and may be recovered for the United States in a civil action brought by the Commission in the Federal District Court for the District of Columbia or for the district in which the violation occurs." (emphasis added)).

201 See Ninestar Tech. Co. v. ITC, 667 F.3d 1373, 1377 (Fed. Cir. 2012) (“Assessment of a civil penalty under 19 U.S.C. $\S 1337$ (f) is reviewed on the standard of abuse of discretion . . .." (citation omitted)); Genentech, Inc. v. USITC, 122 F.3d 1409, 1414 (Fed. Cir. 1997). This means that an ITC ruling is reviewed for whether it: "(1) is clearly unreasonable, arbitrary, or fanciful; (2) is based on an erroneous conclusion of law; (3) rests on clearly erroneous fact findings; or (4) follows from a record that contains no evidence on which the decision-making body could rationally base its decision." Ninestar, 667 F.3d at 1379 (quoting Genentech, 122 F.3d at 1415). Commission penalties may also trigger constitutional review if due process concerns are raised. See Ninstar, Ninestar, 667 F.3d at 1382.

202 Ninestar, 667 F.3d at 1379 (citing San Huan New Materials High Tech, Inc. v. ITC, 161 F.3d 1347, 1362 (Fed. Cir. 1998)). Ninestar also confirms that the ITC, as well as the district courts, has the authority to determine and enforce civil penalties. See id. at 1384. 
Congress in the legislative history [of section 337(f)(2) ], viz., the desire to deter violations, the intentional or unintentional nature of any violations, and the public interest." 203 A Commission interested in ensuring that patentees are compensated but unwilling to exclude products altogether might be able to use this authority to effectively "preannounce" the penalty for violating an exclusion order - in effect converting that penalty into a price to be paid for the importation of infringing goods.

\section{Exercising Discretion Wisely}

The ITC has broad discretion within the bounds of section 1337 to set and shape the remedy for infringement. ${ }^{204}$ It should exercise its remedial flexibility when the risk of holdup is substantial. Holdup is likely when the defendant sells a multicomponent product and the novel feature of the patent covers only a small part of that product. ${ }^{205}$ Different remedies might be appropriate in different situations that present holdup problems. For example, when companies design interoperable products to work together, switching costs become high once the standards are implemented. ${ }^{206}$ In this case, grandfathering in of existing models can ameliorate the harms.

Another issue arises when switching, costly or not, imposes significant harm on customers who cannot get support or service for products already sold; the short-term impact on consumers is high in these cases. ${ }^{207}$ Here, either a stay or an exception allowing service and spare parts might help solve these problems. ${ }^{208}$

Third, in multicomponent cases, collateral damage to third parties who

\footnotetext{
203 San Huan, 161 F.3d at 1362 (second alteration in original).
}

20419 U.S.C. $\S 1337$ (c) (providing that review of remedial decisions is subject to deference under the Administrative Procedure Act, including presumably Chevron deference to reasonable interpretations of the statute).

205 Patent claims will often be written to cover an entire product even though the patentee's contribution is limited to a single small feature. The inventor of the intermittent windshield wiper, for instance, might claim a car with an intermittent windshield wiper. The Commission should focus on what the patentee actually contributed to the art, not the form in which the patentee chooses to write the claim. See Mark A. Lemley, Point of Novelty, 105 Nw. U. L. REV. 1253, 1255 (2011).

206 See, e.g., Certain Baseband Processor Chips and Chipsets, Transmitter and Receiver (Radio) Chips, Power Control Chips, and Products Containing Same, Including Cellular Telephone Handsets, Inv. No. 337-TA-543, USITC Pub. 4258, at 149 (June 19, 2007) (Final) (Commission Opinion on Remedy, the Public Interest, and Bonding) ("As to competitive conditions in the U.S. economy, exclusion would likely result in some adverse impact on the development of advanced telecommunications technology and on expansion of broadband internet access. These technologies are important in their own right, but they also have significant effects on other economic activity in the United States. Downstream relief would make it more difficult for telecommunications companies to expand $3 \mathrm{G}$ cellular telephone services and broadband internet access, and make it more difficult for consumers, including businesses, to access these services.").

207 See Certain Personal Data and Mobile Communications Devices and Related Software, Inv. No. 337-TA-710, USITC Pub. 4331, at 72-73 (July 15, 2011) (Final) (Commission Opinion).

208 See id. at 72, 79-84. 
make noninfringing products may be high because those third parties have already made irreversible investments. Grandfathering can help in some of these cases, but not all; bonding may be the best remedy in this circumstance. ${ }^{209}$

Finally, the ITC may wish to consider three other factors in setting remedies: whether the patentee is a PAE, whether the defendant is a willful infringer, and whether the patent is standards-essential. While the statutory public interest factors are party neutral, ${ }^{210}$ the patentee's status as a PAE can influence the impact of an exclusion order to competition and consumers since it affects the patentee's need for an injunction (a competitive condition) and, when many defendants are sued, the likelihood that consumers will have access to alternative products.

In a similar vein, we believe that the ITC should generally not grant injunctions for standards-essential patents, in particular those that are subject to reasonable and nondiscriminatory (RAND) licensing obligations. The ITC has the power to reject an exclusion order where the respondent is licensed to import the product. ${ }^{211}$ Whether or not a RAND commitment to a standard-setting organization is an executable license, ${ }^{212}$ competition and consumers would be disserved if patents that were promised to be available for licensing on fair and reasonable terms were the basis of exclusion orders. ${ }^{213}$ And if the suit were brought late in the product life cycle, after a standard has been adopted, ${ }^{214}$ switching costs to consumers and competitors

209 See Baseband Processor Chips, Inv. No. 337-TA-543, at 153 (Commission Opinion on Remedy, the Public Interest, and Bonding) ("The potential harm to economic actors, in this case including handset manufacturers and telecommunications service providers, is properly part of our EPROMs analysis, and we have indeed fully weighed potential harm to third parties and to legitimate trade in that prior analysis. In fact, under our EPROMs analysis, we found that full downstream relief was not permitted in this investigation due to, among other things, the magnitude of the impact on third parties."); id. at 153-54 (concluding that "a downstream remedy with a grandfathering exception does not raise public interest concerns" because "the relief we propose has a much more limited impact on availability of 3G-capable handsets, and thus a lesser impact on the public interest"). More generally, Greg Sidak has developed a detailed taxonomy for applying the public interest factors to holdup situations. Sidak, Law and Economics, supra note 126 , at $60-93,170-72$.

210 See 19 U.S.C. $§ 1337$ (c) (2006). In contrast, the domestic industry requirement is not, as the ITC currently interprets, party-neutral. NPEs do not need to prove the so-called technical prong that requires "articles protected by the patent." Id. § 1337(a)(3). One of us has argued that this is inconsistent with the statute and its legislative history. See Chien, Protecting Domestic Industries, supra note 70 , at $180-81$.

211 Tessera, Inc. v. ITC, 646 F.3d 1357, 1370-71 (Fed. Cir. 2011).

212 For an argument that it is an executable license, see Lemley, Intellectual Property Rights, supra note 23, at 1925 .

213 See generally Richard J. Gilbert, Deal or No Deal? Licensing Negotiations in StandardSetting Organizations, 77 ANTITRUST L.J. 855 (2011) (discussing RAND commitments and effects on competition); Suzanne Michel, Bargaining for RAND Royalties in the Shadow of Patent Remedies Law, 77 ANTITRUST L.J. 889 (2011) (same).

214 Research by Brian Love shows that NPEs tend to assert their patents late in the life of the patent, as compared to practicing entities. See Brian J. Love, An Empirical Study of Patent Litigation Timing: Could a Patent Term Reduction Decimate Trolls Without Harming 
would likely be higher. The Department of Justice has expressed similar concerns about using such patents to get injunctions, noting that:

F/RAND requirements have not prevented significant disputes from arising in connection with the licensing of [standards-essential patents (SEPs)], including actions by patent holders seeking injunctive or exclusionary relief that could alter competitive market outcomes.... [T] he division continues to have concerns about the potential inappropriate use of SEPs to disrupt competition . . . . 215

At the same time, companies shouldn't be encouraged to copy and take their chances while infringing based on the absence of injunctive relief. This concern isn't much of a problem in the information technology industries today; the evidence suggests that virtually all defendants in patent cases are innocent infringers, not copiers. ${ }^{216}$ But proof of deliberate infringement should incline the Commission to look askance at claims that the defendant needs an opportunity to design around a patent; the intentional infringer presumably has had that opportunity already. ${ }^{217}$

In addition to the substantive changes discussed above, we make a procedural suggestion. One downside of increased tailoring of ITC exclusion orders is that it could lead to increased unpredictability as to the remedy, at least in the short term. Currently, summary determination proceedings in the $\mathrm{ITC}^{218}$ rarely if ever involve issues of remedy. ${ }^{219} \mathrm{But}$ nothing prevents litigants from bringing such motions. Indeed, the ITC's

Innovators?, U. PA. L. REV. (forthcoming 2012) (manuscript at 3), available at http://papers.ssrn.com/sol3/papers.cfm?abstract_id=1917709.

215 Statement of the Department of Justice's Antitrust Division on Its Decision to Close Its Investigations of Google Inc.'s Acquisition of Motorola Mobility Holdings Inc. and the Acquisitions of Certain Patents by Apple Inc., Microsoft Corp. and Research in Motion Ltd., U.S. DEP'T OF JUSTICE (Feb. 13, 2012), www.justice.gov/opa/pr/2012/February/12-at-210.html.

216 Christopher A. Cotropia \& Mark A. Lemley, Copying in Patent Law, 87 N.C. L. Rev. 1421, 1424 (2009).

217 We use the term "deliberate infringement" rather than "willfulness" here because patent law's willfulness doctrine varies in significant ways from what an ordinary observer would think of as purposeful conduct. Because willfulness is a continuing offense, patent law may designate someone willful merely because she didn't stop selling the product once sued. See Mark A. Lemley \& Ragesh K. Tangri, Ending Patent Law's Willfulness Game, 18 BERKELEY TECH. L.J. 1085, 1089-93 (2003). That behavior is not deliberate conduct in any normal sense. On the other hand, patent law will not find willfulness if the defendant's conduct was objectively reasonable, even if the defendant intended to infringe. See In re Seagate Tech., LLC, 497 F.3d 1360, 1371 (Fed. Cir. 2007) (en banc); id. at 1385 (Newman, J., concurring) ("[T]he standard of 'recklessness' appears to ratify intentional disregard ....").

21819 C.F.R. $\$ 210.18$ (2012) prescribes the procedures that are used for summary determination. As subsection (b) describes:

The determination sought by the moving party shall be rendered if pleadings and any depositions, answers to interrogatories, and admissions on file, together with the affidavits, if any, show that there is no genuine issue as to any material fact and that the moving party is entitled to a summary determination as a matter of law.

19 C.F.R. $§ 210.18$ (b) (2012).

219 See Czebiniak, supra note 8, at 107. 
recent move to allow for earlier briefing on public interest issues seems to support just this possibility. ${ }^{220}$ If a case is not one in which an exclusion order is appropriate, all parties benefit from making that clear up front before unnecessarily litigating questions of validity and infringement.

Finally, we suggest that the ITC consult with other government agencies in appropriate cases. ${ }^{221}$ On several occasions, the ITC has relied on the policies of other parts of the government to support its decision making. In two out of the three cases in which the ITC declined to award an exclusion order, it relied upon the policies of the President and Congress to explain its position. ${ }^{222}$ In Baseband Processor Chips, where the ITC custom tailored the injunction it ordered, the Commission cited the public comments of the Federal Emergency Management Agency and the Federal Communications Commission. ${ }^{223}$ In the ITC's recent Personal Data and Mobile Communications Devices decision, in which it delayed the start of the exclusion order for four months, the Commission drew from statements of the Department of Justice and President Barack Obama to support its decision making. ${ }^{224}$ Historically, there have been few instances of agencies submitting formal comments to ITC investigations, ${ }^{225}$ but where a proposed exclusion order poses a danger to the public interest, other agencies can and

\footnotetext{
22019 C.F.R. $\S 210.8, .10(\mathrm{~b}), .14(\mathrm{f}), .42(\mathrm{a})(1)(\mathrm{ii})(\mathrm{C}), .50(\mathrm{a})(4)$.
}

221 The ITC is required to "consult with, and seek advice and information from, the Department of Health and Human Services, the Department of Justice, the Federal Trade Commission, and such other departments and agencies as it considers appropriate." 19 U.S.C. § 1337(b)(2) (2006).

222 See Certain Inclined-Field Acceleration Tubes and Components Thereof, Inv. No. 337-TA-67, USITC Pub. 1119, at 23-24 (Dec. 29, 1980) (Final) (Commission Action and Order) (citing in support of its decision not to grant an order enjoining Dowlish tubes used for research the fact that "the President and the Congress have issued declarations of support for basic science research" and that "Congress authorizes and directs the National Science Foundation" to conduct research for the benefit of the general welfare); Certain Automatic Crankpin Grinders, Inv. No. 337-TA-60, USITC Pub. 1022, at 20 (Dec. 17, 1979) (Final) (Opinion of Vice Chairman Alberger and Commissioners Bedell and Stern) (justifying its decision not to exclude efficient crankpin grinders in part by "the fact that Congress and the President have also clearly established a policy requiring automotive companies to increase the fuel economy of the automobiles they produce"); see also supra notes 95-97 and accompanying text (describing the three cases in which the Commission did not grant an exclusion order).

223 Certain Baseband Processor Chips and Chipsets, Transmitter and Receiver (Radio) Chips, Power Control Chips, and Products Containing Same, Including Cellular Telephone Handsets, Inv. No. 337-TA-543, USITC Pub. 4258, at 144-46 (June 19, 2007) (Final) (Commission Opinion on Remedy, the Public Interest, and Bonding).

224 Certain Personal Data and Mobile Communications Devices and Related Software, Inv. No. 337-TA-710, USITC Pub. 4331, at 29-31 (July 15, 2011) (Final) (Commission Opinion).

225 Our search of the U.S. ITC Electronic Document Information System for the term "comments" in section 337 actions yielded a handful of agency comments, see, for example, Certain Wireless Communication Devices, Portable Music and Data Processing Devices, Computers and Components Thereof, Inv. No. 337-TA-745 (June 6, 2012) (Final) (Third Party United States Federal Trade Commission's Statement on the Public Interest), as well as comments from Congress and a few states. 
should weigh in during the ITC review process. ${ }^{226}$

\section{CONCLUSION}

eBay has had the unintended consequence of driving patentees to the ITC in hopes of obtaining an injunction no longer available in the federal district courts. Though eBay's flexible four-factor test doesn't apply at the ITC, the Commission has more power to adjust the remedies it grants than commentators have previously recognized. The ITC should use this power to limit exclusion orders in circumstances in which the patentee can hold up defendants. Delaying implementation of exclusion orders and grandfathering in existing products can avoid holdup problems. Bond and penalty provisions can ensure compensation for patentees who experience ongoing infringement during these transition periods, and a few tweaks to the statutory language would give the ITC still more freedom to tailor its remedies. The resulting system won't look exactly like $e B a y$, but it will accomplish many of the same ends.

226 We also encourage greater coordination between innovation and competition agencies. See, e.g., Hearing on the ITC and Patent Disputes, supra note 10, at 3 (statement of Albert A. Foer, President, American Antitrust Institute). 
APPENDIX A

ITC DEFENDANTS (PAE CASES) Jan. 2011-June 2012

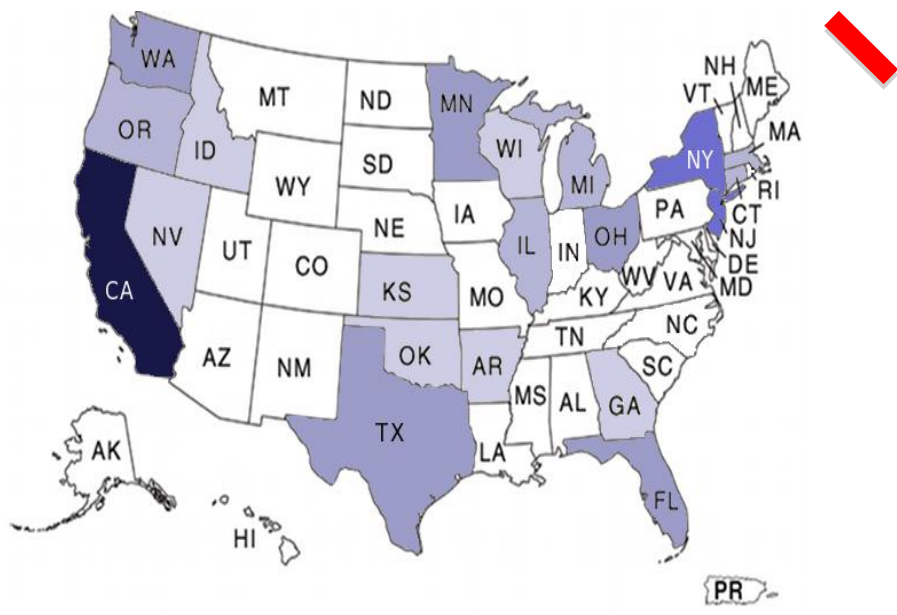

$\{P R=$
FOREIGN

DEFENDANTS:

123

\section{US DEFENDANTS: \\ 209}

CA: 92

NJ: 25

NY: 14

TX: 14

GE: 10

MI: 5

OTHER 
Figure 1: District Court InJUNCTION-GRANT RATES by ENTITy TyPe (July 2006 TO August 2011)

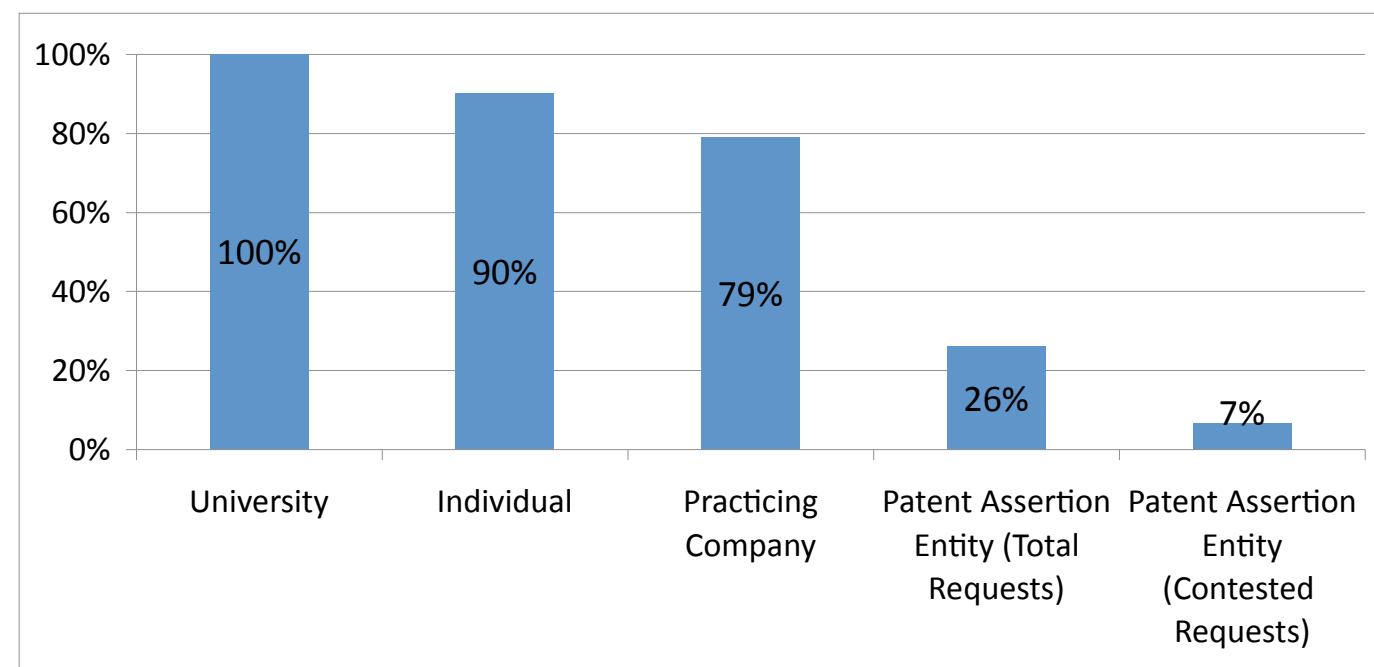

\begin{tabular}{|c|c|c|c|c|}
\hline Category & Grant Rate & Granted & Denied & Total \\
\hline University/Research Organization & $100 \%$ & 3 & 0 & 3 \\
\hline Individual & $90 \%$ & 9 & 1 & 10 \\
\hline Practicing Company $^{1}$ & $79 \%$ & 126 & 33 & 159 \\
\hline PAEs $^{2}$ (total requests) & $26 \%$ & 5 & 14 & 19 \\
\hline PAEs $^{3}$ (contested requests) & $7 \%$ & 1 & 14 & 15 \\
\hline
\end{tabular}

1 This category includes cases brought by i4i, LP, and US Philips Corp., the patent subsidiaries of operating companies i4i, Inc. and Koninklijke Philips Electronics N.V. (Royal Philips Electronics), respectively. See U.S. Philips Corp. v. Iwasaki Elec. Co., 505 F.3d 1371, 1373 (Fed. Cir. 2007) (“U.S. Philips Corporation is 'an IP holding company on behalf of ... the overall Philips organization' and has no employees."); U.S. Philips Corp. v. Iwasaki Elec. Co., No. 03 Civ. 0172 (PKC), 2006 U.S. Dist. LEXIS 71276, at*13 (S.D.N.Y. Sept. 28, 2006) ("The Local Rule 1.9 Statement filed by U.S. Philips reveals that there is a public affiliate known as 'Koninklijike Philips Electronics N.V."'), aff'd in part, vacated in part, and remanded, 505 F.3d 1371 (Fed. Cir. 2007).

2 We identified PAEs using internet research and case pleadings.

3 For a description of the reasoning of these cases, see infra note 57. 
Figure 2: Number of Defendants Per CASE in the ITC ANd District Courts Before AND After PASSAge of THE AMERICA INVENTS ACT

(2011)

ITC

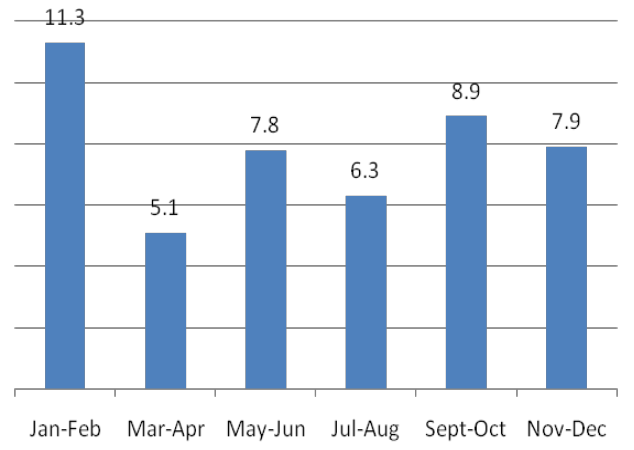

District Court

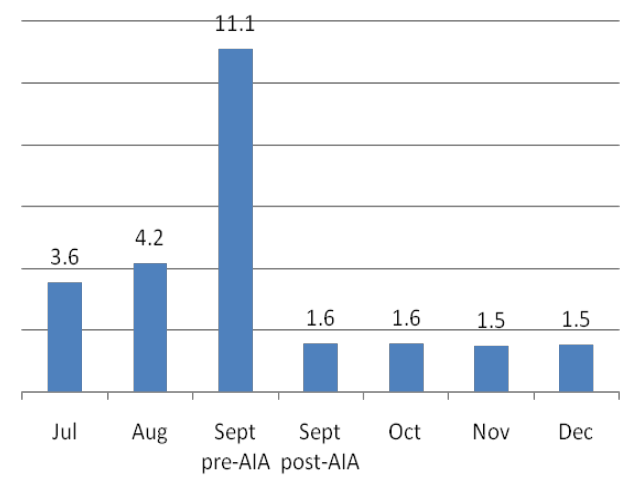

Figure 3: InJunCtion-Grant RATE IN THE ITC AND District COURTS PRE- AND Post-EBAY

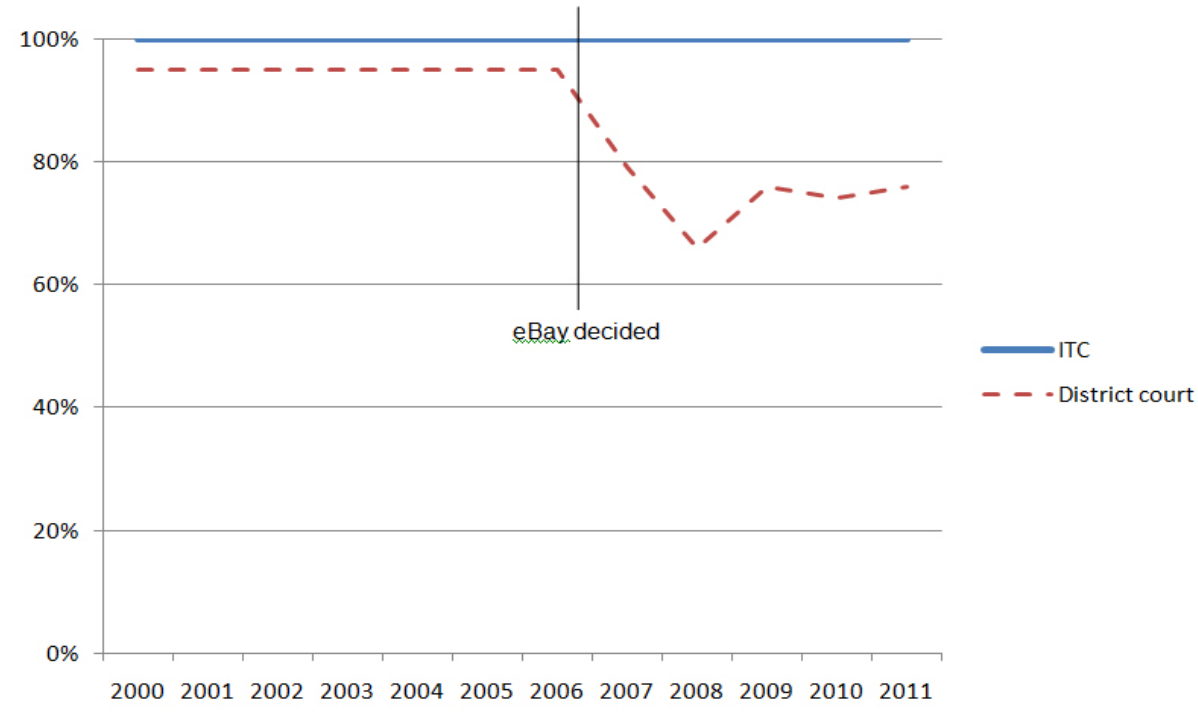




\section{Figure 4: Percentage of CASES AND Respondents In the ITC InVOlving NPEs ${ }^{4}$}

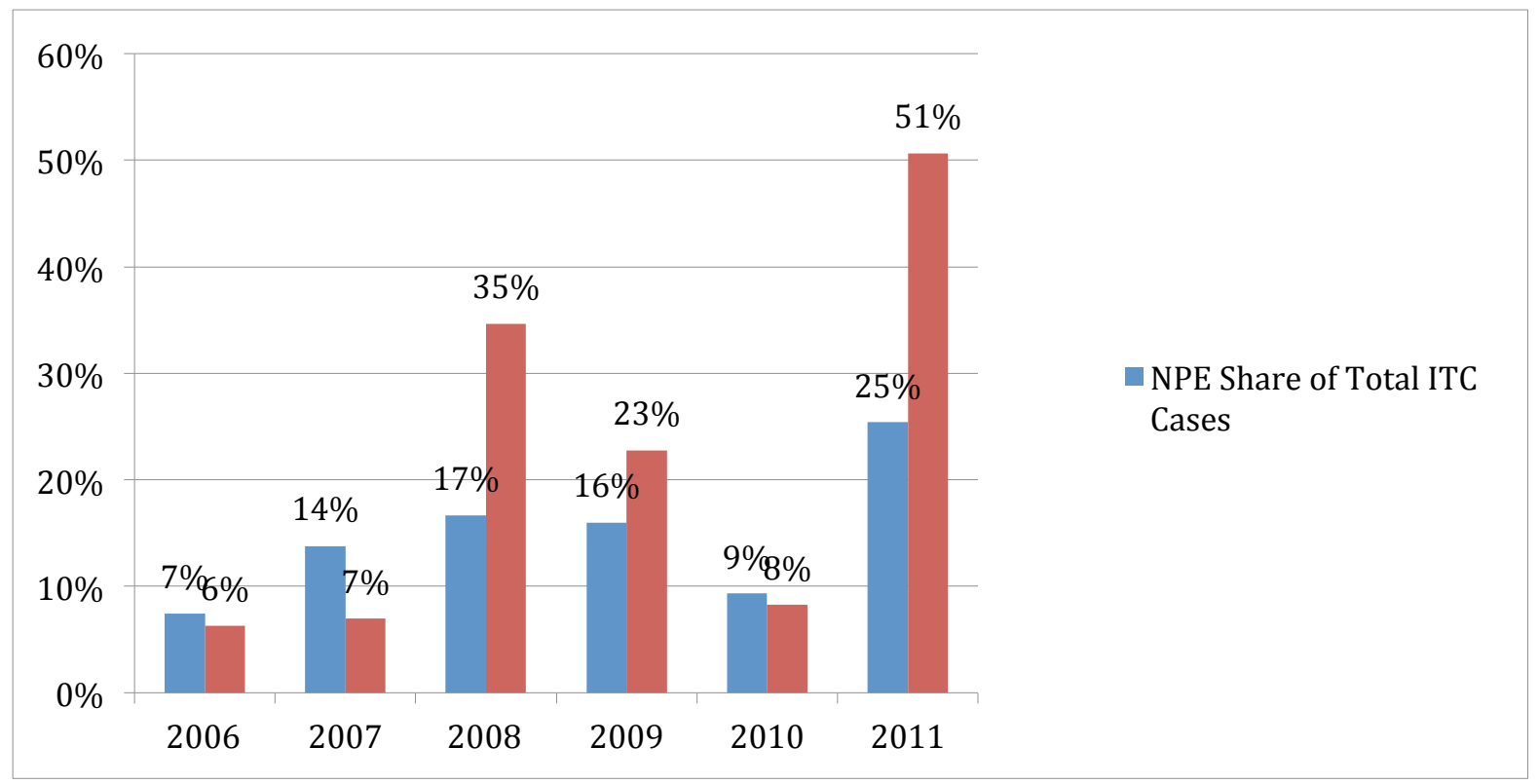

\footnotetext{
${ }^{4}$ As a point of comparison, the ITC's official statistics show that (based on a visual estimate of their graphs), in 2011, Category 1 and 2 NPEs brought $19 \%$ of suits and named $42 \%$ of defendants. See FACTS AND TRENDS, supra note 84, at 2, 4 .
} 